\title{
Mast Cells in the Developing Brain Determine Adult Sexual Behavior
}

\author{
(Dathryn M. Lenz, ${ }^{1,2,3 \star}$ Lindsay A. Pickett, ${ }^{4,5 *}$ @Christopher L. Wright, ${ }^{4,5}$ Katherine T. Davis, ${ }^{4,5}$ Aarohi Joshi, ${ }^{1}$ \\ and $\odot$ Margaret M. McCarthy ${ }^{4,5}$ \\ ${ }^{1}$ Department of Psychology, ${ }^{2}$ Department of Neuroscience, and ${ }^{3}$ Institute for Behavioral Medicine Research, The Ohio State University, Columbus, Ohio \\ 43210; and ${ }^{4}$ Department of Pharmacology and ${ }^{5}$ Program in Neuroscience, The University of Maryland School of Medicine, Baltimore, Maryland 21201
}

\begin{abstract}
Many sex differences in brain and behavior are programmed during development by gonadal hormones, but the cellular mechanisms are incompletely understood. We found that immune-system-derived mast cells are a primary target for the masculinizing hormone estradiol and that mast cells are in turn primary mediators of brain sexual differentiation. Newborn male rats had greater numbers and more activated mast cells in the preoptic area (POA), a brain region essential for male copulatory behavior, than female littermates during the critical period for sexual differentiation. Inhibiting mast cells with a stabilizing agent blunted the masculinization of both POA neuronal and microglial morphology and adult sex behavior, whereas activating mast cells in females, even though fewer in number, induced masculinization. Treatment of newborn females with a masculinizing dose of estradiol increased mast cell number and induced mast cells to release histamine, which then stimulated microglia to release prostaglandins and thereby induced male-typical synaptic patterning. These findings identify a novel non-neuronal origin of brain sex differences and resulting motivated behaviors.
\end{abstract}

Key words: behavior; development; hormone; mast cells; microglia; sex differences

\section{Significance Statement}

We found that immune-system-derived mast cells are a primary target for the masculinizing hormone estradiol and that mast cells are in turn primary mediators of brain sexual differentiation. These findings identify a novel non-neuronal origin of brain sex differences and resulting motivated behaviors.

\section{Introduction}

Elucidating the neural underpinnings that regulate complex social and motivated behaviors remains one of the unmet goals of neuroscience. Mating is a tightly orchestrated, hormonally driven behavior that is expressed differently in males and females as a result of sexual differentiation of the brain early in development. The preoptic area (POA) is an essential brain region for expres-

Received May 9, 2018; revised July 3, 2018; accepted July 23, 2018.

Author contributions: K.M.L. wrote the first draft of the paper; K.M.L., L.A.P., C.L.W., and M.M.M. edited the paper; K.M.L., L.A.P., C.L.W., and M.M.M. designed research; K.M.L., L.A.P., C.L.W., K.T.D., and A.J. performed research; K.M.L., L.A.P., C.L.W., and A.J. analyzed data; K.M.L. and M.M.M. wrote the paper.

This work was supported by the National Institutes of Health (Grant R01 MH052716 to M.M.M., Grant F31NS093947 to L.A.P., and Grants F32NS076327 and R21MH105826 to K.M.L.) and The Ohio State University (Startup Funds to K.M.L.). We thank Shyama Patel from the Weill Cornell Medical College for assistance and training in brain mast cell isolations and The Ohio State University Targeted Metabolomics Laboratory for access to their LC-MS/MS equipment funded by the Translational Plant Sciences Targeted Investment in Excellence (TIE) and for performing LC-MS/MS analysis of histamine turnover in brain tissue.

The authors declare no competing financial interests.

*K.M.L. and L.A.P. contributed equally to this work.

Correspondence should be addressed to Kathryn M. Lenz, Department of Psychology, The Ohio State University, 1835 Neil Ave, Columbus OH, 43210. E-mail: lenz.56@osu.edu.

DOI:10.1523/JNEUROSCI.1176-18.2018

Copyright $\odot 2018$ the authors $\quad 0270-6474 / 18 / 388044-16 \$ 15.00 / 0$ sion of male copulatory behavior and embedded therein are multiple sex differences in neuron, astrocyte, and microglial number and morphology (Hull et al., 2002). Establishing the cellular mechanisms by which sex differences are established provides unique insight into the neural control of behavior.

In perinatal male rodents, testicular androgens are converted to estrogens by neuronal aromatase and estrogens then induce masculinization of brain and behavior (Wu et al., 2009). Treatment of newborn female rodents with testosterone or its active metabolite, estradiol, induces masculinization via a complete phenotypic switching of neuroanatomical and behavioral endpoints (McCarthy, 2008). We previously determined that the inflammatory signaling molecule prostaglandin E2 (PGE2) is induced by estradiol in the neonatal POA and is both necessary and sufficient for the masculinization process (Amateau and McCarthy, 2004). In males, microglia exhibit a morphology consistent with a higher degree of activation and production of inflammatory signaling molecules, including PGE2. The presence of activated (ameboid-like) microglia is both necessary and sufficient to induce masculinization of the synaptic profile as a result of elevated PGE2 (Lenz et al., 2013; VanRyzin et al., 2016). We now report the surprising finding that mast cells, which are 
bone-marrow-derived innate immune cells activated by peripheral allergy, anaphylaxis, and atopy (Silver and Curley, 2013), are key players in brain sexual differentiation by acting as upstream activators of microglia, which then release PGE2 to induce dendritic spine formation.

\section{Materials and Methods \\ Animals}

All experimental procedures were approved by the Institutional Animal Care and Use Committees at either the University of Maryland School of Medicine or The Ohio State University and conducted with Sprague Dawley rats purchased from Envigo Laboratories (formerly Harlan Laboratories) or bred in-house from animals originally from Envigo Laboratories. Animals were housed on a reversed $12 \mathrm{~h}$ light/dark cycle in standard group cages, except when breeding, with food and water provided ad libitum. Adult females were paired with males and separated when vaginal lavage was sperm-positive. Once sperm-positive, pregnant females were isolated and allowed to deliver naturally. Rat pups used in experiments were birthed in-house and pups from multiple litters were randomly assigned to experimental treatment and then randomly distributed back to dams to control for differences in maternal care. Cages were checked daily to determine the day of birth, which was designated postnatal day $0(\mathrm{P} 0)$.

\section{In vivo treatments}

Intracerebroventricular injections. Bilateral intracerebroventricular injections were performed under cryoanesthesia on P0-P1. A 23 gauge $1 \mu \mathrm{l}$ Hamilton syringe attached to a stereotaxic manipulator was placed $1 \mathrm{~mm}$ caudal to bregma and $1 \mathrm{~mm}$ lateral to the midline, lowered $3.0 \mathrm{~mm}$ into the brain, and then backed out $1 \mathrm{~mm}$. One microliter of drug or vehicle was infused over $60 \mathrm{~s}$ and then the procedure was repeated on the other hemisphere. Compound 48/80 (Sigma-Aldrich; dose: $1 \mu \mathrm{g} / 2 \mu \mathrm{l}$ total) or $1 \mu \mathrm{g} / 2 \mu \mathrm{l}$ total of a 50:50 mixture of $0.5 \mu \mathrm{g} / \mu \mathrm{l} \mathrm{H} 1$ and $0.5 \mu \mathrm{g} / \mu \mathrm{l} \mathrm{H} 4$ receptor antagonists (centirizine and A943931; Tocris Bioscience) was delivered in sterile saline vehicle and control animals were treated bilaterally with the same vehicle. The dose of compound $48 / 80$ used was determined based on previously published studies (Nautiyal et al., 2012) and our own validation studies ( presented herein) showing its effectiveness at inducing mast cell degranulation.

Subcutaneous and intraperitoneal injections. Animals were treated subcutaneously with sesame oil vehicle or $17 \beta$-estradiol (E2; Sigma-Aldrich; dose: $100 \mu \mathrm{g} / 0.1 \mathrm{cc}$ sesame oil) on P0-P1 and killed on P2. Bromodeoxyuridine (BrdU) is a thymidine analog incorporated into dividing cells for $\sim 2 \mathrm{~h}$ following injection. BrdU was administered intraperitoneally on P1-P2 (Sigma-Aldrich; dose: $100 \mathrm{mg} / \mathrm{kg}$ in sterile saline) and animals were killed $6 \mathrm{~h}$ following final injection on P2. Tissue used in other experiments was collected at specified time points.

Ad libitum administration of ketotifen in pregnant dams' drinking water. Pregnant dams were treated with the mast cell stabilizer ketotifen fumarate (Sigma-Aldrich, cat\# K2628), which was added to ad libitum drinking water from gestational day 17 , through delivery, until P7. Length of gestation and circadian timing of parturition did not vary because of ketotifen treatment. Ketotifen-treated dams drank an average of $36.75 \pm$ $7.304 \mathrm{ml} / \mathrm{d}$ and were indistinguishable from vehicle controls (41.65 \pm 7.532). Dam body weights before and after delivery and pup body weights were not affected by ketotifen treatment. Final ketotifen doses averaged $26.3 \pm 1.680 \mathrm{mg} / \mathrm{kg} / \mathrm{d}$ to the dam.

\section{In vitro primary cell isolations}

Microglia and mast cell isolation. Brain mast cell and microglia isolations were performed on male and female pups (P2-P3) using methods published previously (Krishnaswamy and Chi, 2006; Patel et al., 2013) and included a whole-brain tissue homogenization under a $15 \min 0.5 \%$ trypsin (Invitrogen) and 1\% DNASE digestion. After suspension in a $37 \%, 50 \%, 70 \%$ Percoll gradient and centrifugation at $1200 \times g$ for 40 min, microglia were taken from the interphase between $50 \%$ and $70 \%$. Mast cells were later isolated using Percoll separation alone by taking cells from the very bottom of the $70 \%$ phase. Plating densities and mast cell culturing conditions were based on Krishnaswamy and Chi (2006). Mast cells were plated or replated at a density of $7.5 \times 10^{4}$ cells per well for a 24-well plate and $3 \times 10^{5}$ per well for a 6-well plate in 0.5 or $2 \mathrm{ml}$, respectively, of DMEM/F12 50:50 medium (Cellgro) containing 10\% fetal bovine serum (FBS; Fisher Scientific), 1\% penicillin-streptomycinamphotericin (Quality Biological), 1\% L-Glutamine (Cellgro) $100 \mathrm{ng} / \mathrm{ml}$ stem cell factor (SCF) (Peprotech), and $30 \mathrm{ng} / \mathrm{ml}$ rat IL-3 (R\&D Systems), grown overnight, and replated to remove contaminating adherent cells. Thereafter, mast cells were replated every $4 \mathrm{~d}$ and fed with media described above but without penicillin-streptomycin-amphotericin. Mast cells were replated $24 \mathrm{~h}$ before an experiment with media lacking in IL-3 and SCF at a density of $2.0 \times 10^{5}$ cells per well for a 24 -well plate and $12 \times 10^{6}$ per $75 \mathrm{~cm}^{2}$ flask (Corning) containing 0.5 or $24 \mathrm{ml}$ of DMEM/ F12 50:50 medium (Corning, catalog \#16-405-CV) containing 10\% FBS (Fisher Scientific), colony-stimulating factor-1 (CSF, $5 \mathrm{ng} / \mathrm{ml}$ ), and glutamine ( $2 \mathrm{~mm})$. Microglia were then passaged and used within 2 weeks of isolation. Mast cell identity and purity of cultures was verified via toluidine blue staining and fluorescent immunohistochemistry (IHC) against serotonin (5-HT) and mast cell protease 2 (MCPT-2); microglia were verified with fluorescent IHC against CD11b. The absence of neurons and astrocytes in cultures was confirmed with fluorescent IHC against MAP2 and GFAP respectively (as described below).

$P O A$ primary culture. On $\mathrm{P} 0$, the POAs from male and female pups $(n=6-10)$ were microdissected, placed into individual tubes containing $2 \mathrm{ml}$ of HBSS, and digested with $0.25 \%$ trypsin (Invitrogen) and $1 \%$ DNASE for $15 \mathrm{~min}$ at $37^{\circ} \mathrm{C}$ or with papain and enzyme A per the manufacturer's protocol for the neuronal dissociation kit (Miltenyi Biotec). Supernatant was removed and cells were washed and gently triturated with a Pasteur pipette in plating media consisting of DMEM/F12 medium without phenol red, 5\% FBS, and $1 \%$ antibiotic/antimycotic (all Invitrogen) until dissociated. Cell density and viability were determined on a hemacytometer using Trypan blue and plated at 500,000 cells per 25 $\mathrm{mm}$ round poly-lysine-coated coverslip in a $100 \mu \mathrm{l}$ volume in $30 \mathrm{~mm}$ round Petri dishes. After allowing cells to seed for $2 \mathrm{~h}$, cultures were fed with $2 \mathrm{ml}$ of cell culture medium consisting of Neurobasal A medium without phenol red (Invitrogen), 1\% B27 supplement (Invitrogen), and $0.125 \%$ L-glutamine (Sigma-Aldrich) and allowed to acclimate and grow for $24 \mathrm{~h}$ before treatment. In some experiments, the vehicle 2hydroxypropyl-B-cyclodextrin carrier (HPCD) (Sigma-Aldrich, catalog \#H107) or 10 nM estradiol in HCPD (Sigma-Aldrich, catalog \#E4389) were added to culture wells on day in vitro (DIV) 1 . Histamine $(1 \mu \mathrm{g} / \mathrm{ml})$ or saline vehicle was also added to directly to culture wells. The same pharmacological treatments were repeated on DIV2 and $6 \mathrm{~h}$ later, media was removed for PGE2 assay and replaced with $4 \%$ paraformaldehyde (PFA) for IHC for Microtubule-Associated Protein-2 (MAP-2; SigmaAldrich, catalog \#M1406, 1:1000, $24 \mathrm{~h}$ ), as detailed below, to detect spinelike protrusions from the dendrites. MAP-2 protein is not localized in dendritic spines but allows for accurate quantification of spine-like protrusions attributable to diffusion of the diaminobenzidine (DAB) reaction product from the neurites into the spine-like protrusion in cultured neurons (Wright and McCarthy, 2009).

Microglia-free POA cultures. POA primary cultures were depleted of microglia via agitation on the day after plating, DIV1, via our previously published procedure (Lenz et al., 2013), which depletes $\sim 90 \%$ of microglia. Coverslips were shaken at 200 RPM for 30 min to detach microglia, after which the microglia-containing medium was replaced with fresh culture medium. At the conclusion of the experiment, cells were fixed with $4 \%$ PFA in PBS for $10 \mathrm{~min}$ and processed for DAB IHC against MAP-2, as outlined below.

Mast cell conditioned media exchanges. Mast cells $\left(8 \times 10^{6}\right)$ were plated in $24 \mathrm{ml}$ in $75 \mathrm{~cm}^{2}$ flasks and IL-3 and SCF were removed $24 \mathrm{~h}$ before treatment. HPCD vehicle or $10 \mathrm{~nm}$ estradiol in HCPD was added for 30 min before addition of this media to primary mixed neuronal or isolated microglial cultures. To prepare the DIV1 sex-specific neuronal cultures, some had microglia removed by shaking. Then, some of the DIV1 POA neuronal cultures or isolated microglia received $10 \mu \mathrm{M}$ cetirizine $\mathrm{HCl}$ (H1 receptor antagonist) and $10 \mu \mathrm{M}$ A94391 (H4 receptor antagonist) (Tocris Bioscience, catalog \#2577 and \#3753, respectively) or saline vehicle controls. One-half or $1 \mathrm{ml}$ of media was removed from the primary neuronal or isolated microglial cultures and replaced with $1 \mathrm{ml}$ of treated 
mast cell media that was centrifuged at $300 \times g$ for 5 min to remove residual mast cells and supplemented with $\mathrm{H} 1$ and $\mathrm{H} 4$ receptor antagonists, estradiol, or vehicle depending upon the condition to ensure final concentrations remained $10 \mu \mathrm{M}$ and $10 \mathrm{nM}$, respectively. The same treatments were repeated on DIV2 and, 6 h later, media was removed for PGE2 assay. Primary POA neuronal cultures were fixed with 4\% PFA for IHC for MAP-2 to detect spine-like protrusions from the dendrites.

\section{Biochemical Analysis}

PGE2 and PGD2. Mast cell, microglia, primary neuronal culture media, or freshly dissected tissue from the POA were stored at $-80^{\circ} \mathrm{C}$ for PGE2 (Arbor Assays, catalog \#K051) and prostaglandin D2 (PGD2; Cayman Chemicals, catalog \#500151) enzyme immunoassay (EIA). Tissue was homogenized in RIPA buffer containing 1\% Igepal CA630, 0.25\% deoxycholic acid, $1 \mathrm{~mm}$ EDTA, $154 \mathrm{~mm} \mathrm{NaCl}$, and $65 \mathrm{~mm}$ Trizma base, with added protease and phosphatase inhibitors (1:1000). Protein supernatant was extracted after $20 \mathrm{~min}$ of centrifugation at $3000 \mathrm{rpm}$ at $4^{\circ} \mathrm{C}$, and total protein concentration determined via Bradford assay (Bio-Rad). POA tissue samples were prepared for PGE2 extraction by acidifying 200 $\mu$ lof sample with $2 \mathrm{~N}$ hydrochloric acid $(\mathrm{HCl})$ to $\mathrm{pH}$ of 3.5. Samples were then placed on wet ice for $15 \mathrm{~min}$ and centrifuged for $2 \mathrm{~min}$ at $3000 \mathrm{rpm}$ to remove precipitate. C18 reverse phase columns (Thermo Scientific, catalog \#60108-303) were prepared by washing with $10 \mathrm{ml}$ of $100 \%$ ethanol and then $10 \mathrm{ml}$ of $\mathrm{dH} 2 \mathrm{O}$. Isolute SPE Adapters (Biotage, catalog $\# 120-1101)$ were used to fit the syringes onto the columns. Samples were eluted through the column and were then washed with $10 \mathrm{ml}$ of $\mathrm{dH}_{2} \mathrm{O}, 10$ $\mathrm{ml}$ of $15 \%$ ethanol, and $10 \mathrm{ml}$ of hexane. Two milliliters of ethyl acetate (Sigma-Aldrich) was used to elute the samples into a $12 \mathrm{ml}$ polypropylene tube followed by evaporation. All chemicals were obtained from Sigma-Aldrich unless otherwise specified. For PGE2 from neuronal cultures, the manufacturer's high-sensitivity protocol was used and included loading $100 \mu \mathrm{l}$ of sample in triplicate, whereas for tissue-extracted PGE2, microglial, or mast cell media, $50 \mu \mathrm{l}$ of sample was loaded per the manufacturer's standard protocol. Thereafter, $25 \mu \mathrm{l}$ of PGE2-conjugate and $25 \mu \mathrm{l}$ of primary antibody were used for a $2 \mathrm{~h}$ incubation at room temperature (RT) followed by 4 rinses with wash buffer, $30 \mathrm{~min}$ of $100 \mu \mathrm{l}$ of TMB substrate development, and $50 \mu \mathrm{l}$ of $1 \mathrm{~N} \mathrm{HCl} \mathrm{stop.} \mathrm{Absorbance}$ was read at $450 \mathrm{~nm}$ by a Tecan M1000 Infinite and manufacturer standards regressed with a Marquat logistic-4 parameter fit. Extracted samples were corrected for total protein concentration and expressed as picograms of PGE2 per milligram of total protein. For the PGD2 assay, $100 \mu \mathrm{l}$ of cell culture media, or manufacturer's standards was combined with the $100 \mu \mathrm{l}$ of methyl oximating reagent and $50 \mu \mathrm{l}$ of this solution was added to each well in triplicate before addition of $50 \mu \mathrm{l}$ of PGD2MOX AChE tracer and $50 \mu \mathrm{l}$ of primary antiserum and incubation for $1 \mathrm{~h}$ at RT. After 5 rinses with wash buffer, $200 \mu \mathrm{l}$ of Ellman's reagent was added to each well and incubated for $60 \mathrm{~min}$ before reading absorbance at $410 \mathrm{~nm}$ and confirming a minimum 0.3 A.U. absorbance on the $\mathrm{B}_{0}$ well before manufacturer's standards were regressed by Marquat logistic- 4 parameter fit of the $\% \mathrm{~B} / \mathrm{B}_{0}$.

Histamine release in vitro. Mast cells were plated in a 24 -well plate at a density of $1.5 \times 10^{6}$ cells/ $\mathrm{ml}$ and IL-3 and SCF was removed from the media $24 \mathrm{~h}$ before treatment with a vehicle containing 2-HBCD (SigmaAldrich, catalog \#H107) or $10 \mathrm{~nm}$ estradiol immersed in 2-HBCD (Sigma-Aldrich, catalog \#E4389). Thirty minutes later, media was collected from each well, centrifuged at $300 \times g$ for 5 min to remove residual cells, and supernatant diluted 1:50 before assessing histamine levels via EIA (Cayman Chemicals, catalog \#A05890) per manufacturer's protocol.

Histamine release in vivo. Standard $100 \mu \mathrm{M}$ stock of histidine, histamine, methylhistamine, and uniformly labeled ${ }^{13} \mathrm{C}$-glycine were prepared in ultrapure water. Brain samples were dissociated using sonication with tungsten beads, centrifuged, and amine extracted using boiling water ( 4 min incubation in hot water bath) followed by cold acetonitrile/ $0.2 \% \mathrm{w} / \mathrm{v}$ formic acid solution centrifugation, and evaporation of solvents using a speed vacuum. Dried samples were resuspended in $0.1 \%$ formic acid and analyzed using liquid chromatography tandem mass spectrometry (LCMS/MS). The analysis of histamine, methylhistamine, histidine and ${ }^{13} \mathrm{C}-$ glycine (internal standard) was performed using a ultra-high-pressure liquid chromatography 1290 from Agilent Technologies coupled to a
Table 1. Compound parameters for LC-MS/MS

\begin{tabular}{lcclllll}
\hline Metabolite & $\begin{array}{l}\text { Parent } \\
\text { mass }\end{array}$ & $\begin{array}{l}\text { Daughter } \\
\text { mass }\end{array}$ & $\begin{array}{l}\text { Retention } \\
\text { time }(\text { min) }\end{array}$ & $\begin{array}{l}\text { DP } \\
\text { (V) }\end{array}$ & $\begin{array}{l}\text { EP } \\
\text { (V) }\end{array}$ & $\begin{array}{l}\text { CE } \\
\text { (V) }\end{array}$ & $\begin{array}{l}\text { CXP } \\
\text { (V) }\end{array}$ \\
\hline Histamine & 112 & 95 & 3.43 & 70 & 10 & 19 & 14 \\
Histidine & 156 & 110 & 2.43 & 50 & 10 & 21 & 16 \\
Methylhistamine & 126 & 109 & 3.45 & 50 & 10 & 27 & 18 \\
${ }^{13}$ C-glycine & 78 & 31 & 0.84 & 20 & 10 & 19 & 12 \\
\hline
\end{tabular}

DP, Declustering potential; EP, entrance potential; CE, collision energy; CXP, collision cell exit potential.

hybrid triple quadrupole/ion trap mass spectrometer (QTRAP 5500; AB Sciex).

Each pure standard was diluted to $1 \mu \mathrm{M}$ with a solution of acetonitrile/ ultrapure water $(50: 50 ; \mathrm{v} / \mathrm{v})$ containing $0.1 \%$ formic acid. Metabolites were injected individually and directly into the mass spectrometer apparatus at a flow rate of $7 \mu \mathrm{l} / \mathrm{min}$. This step (direct infusion) optimizes four major parameters of a specific metabolite: (1) the declustering potential, (2) the entrance potential, (3) the collision energy potential, and (4) the collision cell exit potential. Compound parameters are shown in Table 1.

The extracts were transferred to glass vials and placed in an autosampler kept at $4^{\circ} \mathrm{C}$. A $20 \mu \mathrm{l}$ aliquot of sample was injected into the column. The liquid chromatography analysis was performed at $30^{\circ} \mathrm{C}$. Metabolites were resolved using a C18 Kinetex biphenyl $(100 \times 2.1 \mathrm{~mm}, 2.6 \mu \mathrm{m})$ column and a security guard column $(10 \times 2.1 \mathrm{~mm})$ from Phenomenex. The gradient used to separate the molecules consisted of ultrapure water with $0.1 \%$ formic acid plus $1 \mathrm{~mm}$ perfluoroheptanoic acid (solvent B) and $0.1 \%$ formic acid in $100 \%$ acetonitrile (solvent A). The total LC-MS/MS run was $8.5 \mathrm{~min}$ with a flow rate of $400 \mu \mathrm{l} / \mathrm{min}$. The gradient went as followed (solvent A): $0-1.0 \mathrm{~min} 10 \%, 1.0-4.0 \mathrm{~min} 50 \%, 4.0-4.1 \mathrm{~min}$ 90\%, 4.1-6.0 $\min 90 \%, 6.0-6.1 \mathrm{~min} 10 \%$, and $6.1-8.5 \mathrm{~min} 10 \%$.

The mass spectra were acquired using turbo spray ionization of $2500 \mathrm{~V}$ in positive ion mode and multiple reaction monitoring. The curtain gas (nitrogen), collision activated dissociation, nebulizing, and heating gas were set to $35 \mathrm{psi}$, medium, $40 \mathrm{psi}$ and $40 \mathrm{psi}$, respectively. The temperature of the source was fixed at $650^{\circ} \mathrm{C}$. The mass spectrometer was set to have a dwell time of $30 \mathrm{~ms}$. LC-MS/MS data were acquired and processed using Analyst 1.6.1 software.

\section{Histology and IHC}

For all in vivo histology experiments, animals were killed via lethal overdose with FatalPlus (Vortech Pharma), followed by transcardial perfusion with saline and then $4 \%$ paraformaldehyde, and then the brains were removed and postfixed for $12 \mathrm{~h}$. Brains were sectioned coronally at $45 \mu \mathrm{m}$ thickness on a cryostat (Leica) and mounted onto SuperFrost charged slides (Fisher Scientific) for subsequent staining procedures.

Mast cell staining. Mast cells were visualized using staining with acidic toluidine blue $(0.5 \%$ in $60 \%$ ethanol, $\mathrm{pH} 2.0)$ as detailed in Nautiyal et al. (2012), sequential acidic Alcian blue $(1 \%$ in $0.7 \mathrm{~N} \mathrm{HCl})$, and safranin $\mathrm{O}$ ( $1 \%$ in 0.125 N HC (all stains from Sigma-Aldrich) or IHC for mast-cellspecific markers as detailed below. Histological stains were performed on separate tissue sections.

IHC and immunofluorescence (IF). Brain sections were rinsed twice with $\mathrm{PBS}$, permeabilized with $0.3 \% \mathrm{H}_{2} \mathrm{O}_{2}$ in $50 \%$ methanol, blocked with $5-10 \%$ bovine serum albumin (BSA) or normal goat serum in PBS + $0.4 \%$ Triton X-100, and incubated with primary antisera for $24-120 \mathrm{~h}$ at $4^{\circ} \mathrm{C}$. For in vitro experiments, coverslips were washed with PBS twice and incubated with primary antisera for $24 \mathrm{~h}$ at $4^{\circ} \mathrm{C}$ containing $10 \% \mathrm{BSA}$ in PBS $+0.4 \%$ Triton X-100. Thereafter, sections or coverslips were extensively washed and either incubated with appropriate fluorescently tagged secondary antibodies for $2 \mathrm{~h}$ (Alexa Fluor 488, 555, 594, or 633, Life Technologies, 1:250) for IF or processed with biotinylated secondary antibodies (Vector Laboratories), avidin-biotin complex (Vector Laboratories), and reacted with $\mathrm{DAB}$ with or without nickel (DAB or Ni-DAB; Sigma-Aldrich) in $0.125 \mathrm{~m}$ sodium acetate to visualize chromogen for IHC. IF tissue was subsequently incubated in Hoescht nuclear stain for 20 min (Invitrogen, catalog \#MP-10338, 1:5000). Stained sections were coverslipped with DPX mounting media or VectaShield Hard Set (Vector Laboratories). Primary antisera used were as follows: MicrotubuleAssociated Protein-2 (MAP-2) (Sigma-Aldrich, catalog \#M1406, 1:1000, 
$24 \mathrm{~h}$ ), estrogen receptor $\alpha$ (ER- $\alpha$ ) (Millipore, catalog \#06-935, 1:10000, 120 h); 5-HT (Abcam, catalog \#sc32292, 1:1000, 24 h); histamine (Abcam, catalog \#ab43870, 1:1000, 24 h); Ibal (Wako, catalog \#019-19741, 1:1000, $24 \mathrm{~h}$ or Novus Biologics, catalog \#NB100-1028, 1:1000, $24 \mathrm{~h}$ ); CD11b (Abcam, catalog \#ab75476, 1:5000, 24 h); The IgE receptor FCER1 (Abcam, catalog \#ab33568, 1:1000, 24 h); rat mast cell protease 2 (RMCPII) (Moredun Scientific, catalog \#MS-RM4, 1:10,000, 24 h) BrdU (BD Biosciences, catalog \#347580, 1:250, 24 h), histamine receptor 1 (Millipore, catalog \#AB5652P, 1:5000, $24 \mathrm{~h}$ ), or histamine receptor 4 (Abcam, catalog \#ab97997, 1:5000, 24 h), GFAP (Sigma-Aldrich, catalog \#G3893, 1:5000, 24 h). Microglia were quantified using Ni-DAB IHC, and proliferating microglia quantified using sequential DAB IHC against Ibal and Ni-DAB against BrdU and colocalization was confirmed in three dimensions using confocal microscopy on IF-stained tissue. Mast cell phenotype, mast cell estrogen receptors, and proliferating mast cells were assessed using IF and imaged with confocal microscopy. For colocalization, primary ER- $\alpha$ and RMCPII antibodies were labeled with secondary antibody conjugated to Alexa Fluor-594 and Alexa Fluor-488 respectively.

\section{Microscopy and stereology}

Stereology and single-cell reconstruction. Either a Nikon Eclipse E600 Microscope or a Zeiss Axioimager.M2 microscope coupled to a CX9000 digital camera and Stereo Investigator software (MBF Bioscience) were used to estimate the total population of mast cells and microglia in the POA using an average of four to six sections per animal encompassing the entire rostrocaudal extent of the POA. At the time of counting, mast cells were categorized as either granulated or degranulated and microglia were categorized as ameboid or not ameboid. Microglia were considered ameboid if they had an enlarged cell body and either no processes or few short processes based on criteria validated in our previously published study (Lenz et al., 2013). Neurolucida software (MBF Bioscience) was used for cell culture image acquisition and analysis. For MAP2-labeled cells and single-cell reconstruction, cells were reconstructed using a $100 \times$ oil objective and were chosen for analysis if they had at least two distinct processes and uniform dark labeling throughout the extent of the cell. Data collected included cell body size, total neurite length, number of neurites, and number of spine-like protrusions from the neurite. Labeled protrusions of $<5 \mu \mathrm{m}$ in length from the neurite were counted as spinelike protrusions. Three to six cells per coverslip were used for the analysis.

Confocal imaging. Double- or triple-labeled IF tissue was imaged using a Zeiss LSM 710 with a $20 \times$ Plan Apocromat 1.0 numerical aperture dipping objective and $z$-stacks acquired using Zen software to determine colocalization of Ibal and BrdU staining (proliferating microglia) and 5-HT and BrdU staining (proliferating mast cells).

\section{Western blot}

Tissue was homogenized in RIPA buffer containing 1\% Igepal CA630, $0.25 \%$ deoxycholic acid, $1 \mathrm{~mm}$ EDTA, $154 \mathrm{~mm} \mathrm{NaCl}$, and $65 \mathrm{~mm}$ Trizma Base, with added protease and phosphatase inhibitors (1:1000). All chemicals were obtained from Sigma-Aldrich unless otherwise specified. Protein supernatant was extracted after $20 \mathrm{~min}$ of centrifugation at 3000 $\mathrm{rpm}$ at $4^{\circ} \mathrm{C}$ and total protein concentration determined via Bradford assay (Bio-Rad). Fifteen micrograms of protein was electrophoresed on an $8-16 \%$ precast SDS polyacrylamide gel (Life Technologies) and transferred onto a single polyvinyl difluoride membrane (Bio-Rad). Membranes were blocked in 50\% Odyssey blocking buffer (LI-COR) in Tris buffered saline (TBS) or $10 \%$ nonfat milk in $0.1 \%$ Tween in Tris-buffered saline (TTBS) and subsequently incubated with spinophillin primary antiserum (Millipore, catalog \#06-842, 1:1000) and beta tubulin primary antiserum (BioLegend, catalog \#801202, 1:3000) in 50\% odyssey blocking buffer or in $5 \%$ milk in TTBS overnight at $4^{\circ} \mathrm{C}$. Membranes were rinsed and incubated with IRDye anti-rabbit 800 and anti-mouse 680 produced in goat $(1: 20,000$, LI-COR) in $50 \%$ odyssey blocking buffer in TTBS containing $0.02 \%$ SDS in the dark or HRP-conjugated secondary antibody (1:200) for $2 \mathrm{~h}$. An Odyssey CLx imaging system was used for detection of fluorescent immunoblots. Spinophillin protein detected was normalized by the $55 \mathrm{kDa} \beta$ tubulin band from each lane as a loading control. A Phototype chemilluminescence system (New England Bio- labs) was used to detect the immunoblots by exposing the membrane to Hyperfield ECL (GE Healthcare). Integrative grayscale pixel area densitometry captured with a CCD camera was quantified with Image software.

\section{Behavior}

Between P50 and P54, animals were gonadectomized under isoflurane anesthesia and implanted subcutaneously with a $30 \mathrm{~mm}$ SILASTIC capsule ( $1.57 \mathrm{~mm}$ inner diameter, $3.18 \mathrm{~mm}$ outer diameter) filled with crystalline testosterone (Sigma-Aldrich) placed between the scapula. This capsule length mimics physiological levels of testosterone circulating in adult males and allows appropriate hormone levels for developmentally masculinized females to perform male-typical copulatory behavior (Amateau and McCarthy, 2004). Two weeks following surgery, animals were video recorded for at least 20 min during the dark phase of the light cycle in a Plexiglas behavioral arena in the presence of a hormonally primed sexually receptive stimulus female under red light illumination. Behavioral data were quantified for every animal by an observer blinded to the experimental treatment of each animal. Measures included number of mounts, latency to mount, ejaculation, latency to ejaculation, and latency to resume mounting after each ejaculation. To record the full post-ejaculatory interval for situations during which a male started a post-ejaculatory interval with some of the $20 \mathrm{~min}$ left, the male was observed beyond the $20 \mathrm{~min}$ period until he resumed mounting. These mounts outside of the 20 min period were not tallied in total mount measures. Mount rate was calculated from the total mounts divided by the $20 \mathrm{~min}$ less the total time during the $20 \mathrm{~min}$ that the animal was in a refractory post-ejaculatory state.

\section{Experimental design and statistical analysis}

Animal or replicate numbers for each experiment are listed in each figure caption. All histological, IHC/IF, Western blot, and culture data were analyzed using one- or two-tailed $t$ tests or one or two-way ANOVA, followed by Tukey's HSD post hoc tests, exclusions below. When normally distributed, behavior data were analyzed with one-way ANOVAs followed by Tukey's HSD post hoc analysis. When not normally distributed, behavior data were analyzed by Mann-Whitney $U$ test correcting $\alpha$-significance for familywise error. Chi-squared analysis was used for IHC for colocalization of ER- $\alpha$ and mast cell protease 2. Overall statistical significance was set at $\alpha=0.05$. Exact $p$-values are presented in figure captions for each dataset and analysis. All data were analyzed using GraphPad Prism or SPSS software and all graphs made using GraphPad Prism. A summary of statistical details are listed in Table 2, including data structure, type of test, test value, and effect size and power estimates where appropriate. The experiments presented herein were not preregistered.

\section{Results}

\section{Mast cells show organizational sex differences in the developing POA}

Mast cells were detected in the POA and their identity confirmed by positive labeling for a variety of markers, including histological staining with toluidine blue, Alcian blue, and safranin, 5-HT, histamine, and the FC $\varepsilon$ receptor 1 (Fig. $1 A$ ). Using quantification of both toluidine-blue-positive cells $\left(F_{\operatorname{int}(8,106)}=5.1, p<0.0001\right.$; Fig. $1 B)$ or 5-HT-positive cells $\left(t_{(10)}=2.273, p=0.046\right.$; Fig. $\left.1 C\right)$ in independent experiments, we found that there are more mast cells in the POA neuropil and adjacent leptomeninges of neonatal male rats than females during the critical window for sexual differentiation at embryonic day 20 (E20) to P7. Thereafter, the mast cell population in males decreases to female levels (Fig. 1B).

To determine whether this sex difference is hormonally mediated, newborn females were treated with a dose of $17 \beta$ estradiol that mimics the levels normally seen in males (Amateau et al., 2004) and the effect on mast cells was measured within $2 \mathrm{~d}$. Using toluidine blue staining, mast cells were detected in the neuropil and meninges of the POA (Fig. $1 A, D)$. The overall num- 
Table 2. Summary of statistical analysis

\begin{tabular}{|c|c|c|c|c|c|}
\hline Figure & Distribution & Type of test & Test value & Effect size & Power \\
\hline $1 B$ & Normal & Two-way ANOVA & $F_{\text {sex } \pm \operatorname{age}(8,106)}=5.1, p<0.0001$ & Partial eta sq: 0.278 & Observed power 0.998 \\
\hline $1 C$ & Normal & Student's $t$ test & $t_{(10)}=2.273, p=0.0463$ & $\eta=1.31, r=0.55$ & \\
\hline $1 E$ total & Normal & One-way ANOVA & $F_{(2,17)}=6.20, p=0.01$ & Eta sq: 0.4218 & \\
\hline $1 E$ percentage & Normal & One-way ANOVA & $F_{(2,17)}^{(2,1)}=6.24, p=0.01$ & Eta sq: 0.3422 & \\
\hline $1 F$ percentage & Normal & One-way ANOVA & $F_{(2,17)}^{(2,1)}=9.22, p=0.002$ & Eta sq: 0.5203 & \\
\hline $1 G$ & Normal & Student's $t$ test & $t_{(9)}=2.518, p=0.033$ & $\eta=1.47 r=0.59$ & \\
\hline $2 B$ & Normal & Student's $t$ test & $t_{(17)}=2.78, p=0.01 ; t_{(17)}=2.95, p=0.01$ & $\eta=1.348, r=0.559 ; \eta=1.431, r=0.582$ & \\
\hline $3 C$ & Normal & One-way ANOVA & $F_{(2,29)}=6.05, p=0.01$ & Eta sq: 0.29 & \\
\hline $3 E$ & Normal & Two-way ANOVA & $\begin{array}{l}F_{\text {time } \pm \text { treat }(3,16)}=0.4491 p=0.7214 \\
F_{\text {time }(3,16)}=2.757 p=0.0764 \\
F_{\text {treat }(1,16)}=0.04739 p=0.8304\end{array}$ & Partial eta sq. $0.078,0.341,0.003$ & $0.121,0.554,0.055$ \\
\hline $3 F$ & Normal & Two-way ANOVA & $\begin{array}{l}F_{\text {time } \pm \text { treat }(3,16)}=0.3392 p=0.7973 \\
F_{\text {time }(3,16)}=87.79 p<0.0001 \\
F_{\text {treat }(1,16)}=2.924 p=0.1066\end{array}$ & Partial eta sq. 0.600 .9430 .115 & 0.1021 .000 .362 \\
\hline $4 A$ & Normal & Student's $t$ test & $t_{(7)}=3.214, p=0.0148$ & $\eta=2.061 r=0.717$ & \\
\hline $4 B$ & Normal & Student's $t$ test & $t_{(8)}=6.185, p=0.0003$ & $\eta=3.911 r=0.89$ & \\
\hline $4 C$ & Normal & One-way ANOVA & $F_{(2,12)}=3.86 p=0.061 \mathrm{HSD}(F \mathrm{vs} F+4880) p=0.779$ & Eta sq: 0.462 & Observed power 0.545 \\
\hline $4 D$ & Normal & One-way ANOVA & $F_{(2,15)}=12.44, p=0.0007$ & Eta sq:0.62 & \\
\hline $4 F$ & Normal & Two-way ANOVA & $F_{\text {treat }(3,19)}^{(2,1)}=32.62, p<0.0001 ; \mathrm{HSD} p<0.01$ & Partial eta sq: 0.68 & Observed power 1.00 \\
\hline $4 G$ & Normal & Two-way ANOVA & $F_{\text {sex } \pm \text { treat }(3,19)}=3.35, p=0.057 ; \mathrm{HSD} p=0.038$ & Partial eta sq: 0.221 & Observed power 0.489 \\
\hline $5 A$ & Normal & One-way ANOVA & $F_{(2,35)}=5.12, p=0.011$ & Eta sq: 0.226 & Observed power 0.789 \\
\hline $5 B$ & Non-normal & $M-W U$ & $M-W U_{M v s F}=36.5 p=0.16$ & & \\
\hline $5 B$ & Non-normal & $M-W U$ & $\mathrm{M}-\mathrm{W} U_{F v s F S t i m}=20, p=0.013$ & & \\
\hline $5 C$ & Normal & One-way ANOVA & $F_{\text {treat }(3,49)}=2.219 p=0.099$ & Eta sq: 0.129 & Observed power 0.527 \\
\hline $5 D$ & Non-normal & $M-W U$ & $M-W U_{M \text { vs Keto }}=34, p=0.013$ & & \\
\hline $5 D$ & Non-normal & $M-W U$ & $\mathrm{M}-\mathrm{W} U_{\mathrm{M} \mathrm{vs} \mathrm{F}}=22.5, p=0.001$ & & \\
\hline $5 E$ & Non-normal & $M-W U$ & $M-W U=130.5, p=0.0135$ & & \\
\hline $5 F$ & Non-normal & $M-W U$ & $\mathrm{M}-\mathrm{W} U=37.5, p=0.021$ & & \\
\hline $6 B$ & Normal & One-way ANOVA & $F_{(2,9)}=11.22, p=0.0036$ & Eta sq: 0.713 & \\
\hline 6C & Normal & Student's $t$ test & $t_{(6)}=0.8195, p=0.4438$ & $\eta=0.67, r=0.317$ & \\
\hline $7 B$ top & Normal & One-way ANOVA & $F_{(4,29)}=7.717, p=0.001, \mathrm{HSD} p=0.024$ & Eta sq: 0.589 & \\
\hline $7 B$ bottom & Normal & One-way ANOVA & $F_{(4,29)}^{(1,29)}=43.82, p<0.001$, HSD $\left.p<0.001\right)$ & Eta sq: 0.898 & \\
\hline 7 ctop & Normal & One-way ANOVA & $F_{(4,29)}^{(4,29)}=66.09, p<0.001$, Tukey's HSD $p<0.001$ all & Eta sq: 0.917 & \\
\hline 7 C bottom & Normal & One-way ANOVA & $\begin{array}{l}F_{(4,29)}=12.43, p<0.001 \text {,Tukey's HSD } p<0.001 \text { and } \\
\quad p=0.027 \text {, respectively }\end{array}$ & Eta sq: 0.674 & \\
\hline 70 & Normal & One-way ANOVA & $F_{(6,44)}=27.82, p<0.001$, Tukey's HSD $p<0.001$ & Eta sq: 0.791 & \\
\hline $7 E$ & Normal & Linear correlation & $R^{2}=0.318, p=0.001$ & & \\
\hline $8 A$ & Normal & One-way ANOVA & $\begin{array}{l}F_{(2,22)}=13.08, p=0.0002 \mathrm{HSD}(\mathrm{M} \text { vs F) } p=0.0255 \\
\quad(\mathrm{Fvs} F+\mathrm{H} 1 / 4 \text { ant }) p=0.255\end{array}$ & Eta sq: 0.543 & \\
\hline $8 B$ & Normal & One-way ANOVA & $F_{(4,32)}=7.16, p<0.001$, Tukey's HSD $p<0.001$ & Eta sq: 0.472 & \\
\hline
\end{tabular}

M-W, Mann-Whitney $U$ test; eta sq = eta squared.

ber of mast cells $\left(F_{(2,17)}=6.20, p=0.01\right.$; Fig. $1 E$, full bars $)$ and the number of mast cells in the neuropil of the POA $\left(F_{(2,17)}=9.22\right.$, $p=0.002$; Fig. $1 F$, full bars) increased to male levels in females treated with a masculinizing dose of estradiol.

Mast cells release secretory vesicles filled with bioactive mediators via a process called degranulation (Silver and Curley, 2013). The number of mast cells with evidence of degranulation was not different between males and females on P2, which is after the fetal male androgen surge (Konkle and McCarthy, 2011), but exogenous estradiol induced acute increases in the percentage of total mast cells showing degranulation in females $\left(F_{(2,17)}=6.24, p=\right.$ 0.01 ; Fig. $1 E$, shaded bars show number of degranulated cells). In agreement, males had a higher percentage of mast cells with evidence of degranulation than females on E20, when endogenous estradiol is high in males (Konkle and McCarthy, 2011) due to the testicular hormone surge $\left(t_{(9)}=2.51, p=0.03\right.$; Fig. $1 G$, shaded bars depict number of degranulated cells).

In a preliminary analysis, we found no evidence of mast cell proliferation in the neonatal POA of either males or females (Fig. 2A). Therefore, sex differences in mast cell number appear to result from hormone-induced recruitment into the POA from nearby regions, the meninges or choroid plexus, or the periphery. After finding no evidence of sex differences in mast cell proliferation, or indeed any mast cell proliferation, in the developing POA, we next assessed whether POA microglia show evidence of proliferation both as a positive control and to increase knowledge regarding sex differences in microglia. We found that microglia readily proliferate in the neonatal POA, with approximately one of every six microglia (stained with Iba1) also being positive for BrdU staining. Moreover, we found more microglia proliferation in the neonatal male POA than in the female POA $\left(t_{(17)}=2.78, p=0.01\right.$; Fig. $\left.2 B-D\right)$.

Given that estradiol had rapid effects on mast cell number in the POA, we sought to determine whether mast cells and their degranulation are directly responsive to estrogens via estrogen receptors. We detected ER- $\alpha$ in $\sim 40 \%$ of mast cells in males and females (Fig. $3 A, B$ ). Estradiol treatment of isolated brain mast cells in vitro induced release of histamine to the same extent as a pharmacological stimulator of degranulation, called compound $48 / 80\left(F_{(2,29)}=6.05, p=0.01\right.$; Fig. $\left.3 C\right)$. In contrast, when assessed at multiple time points in vitro (Fig. $3 D$ ), estradiol had no effect on release of membrane derived PGE2 $\left(F_{\text {treat }(1,16)}=\right.$ 


\section{A}

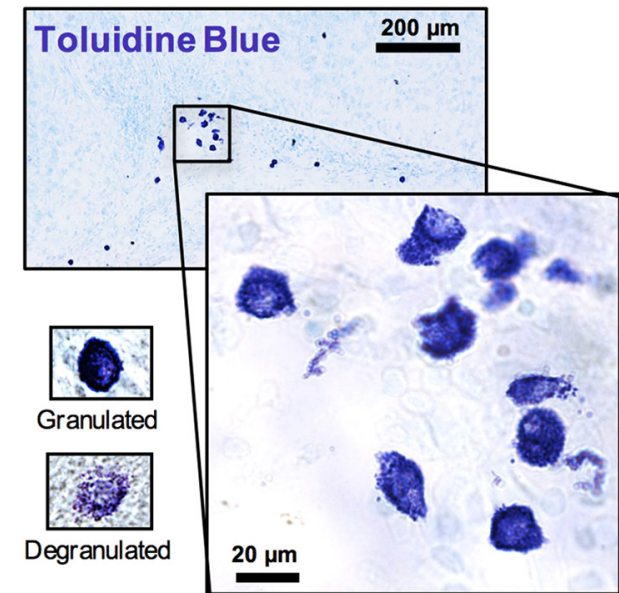

B

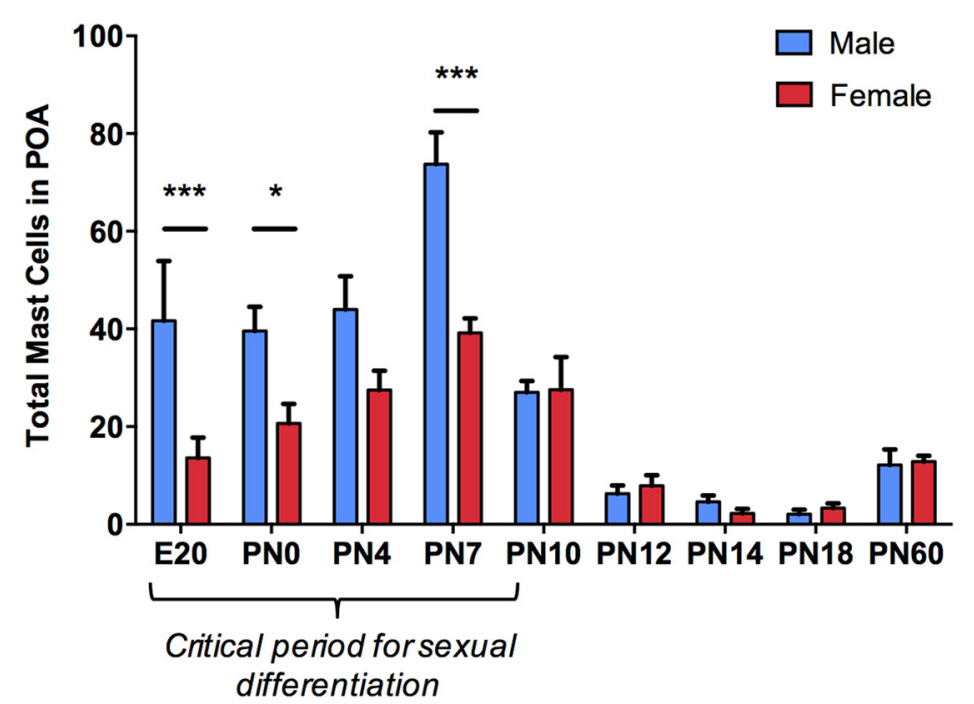

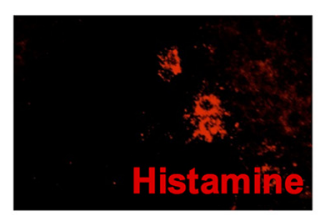

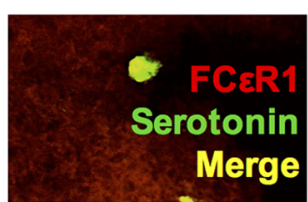

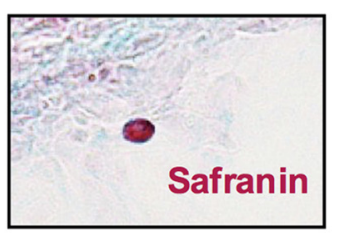

C

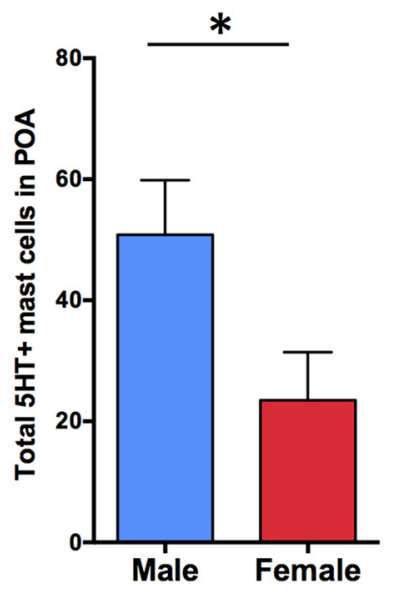

D

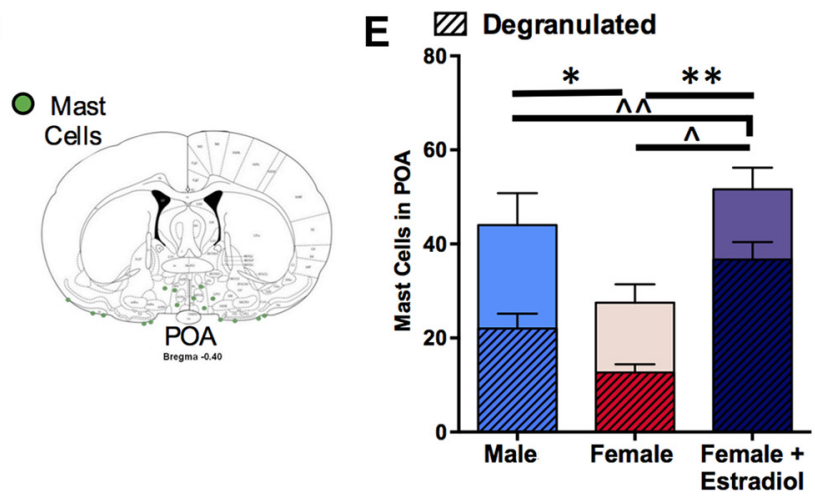

$\mathbf{F}$

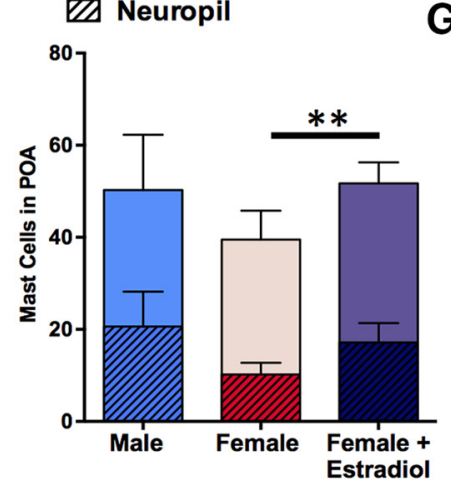

G $\square$ Degranulated

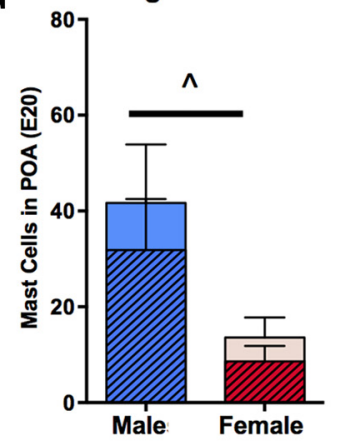

Figure 1. Sex differences in mast cells in the POA during the critical period for sexual differentiation. A, Mast cells in the POA neuropil and leptomeninges on PO stained with toluidine blue (left). Mast cells in the POA stained positive for Alcian blue and immunolabel for 5-HT, histamine, and the lgE receptor FC $\in R 1$ indicating a mucosal phenotype. Occasional safranin-positive mast cells (bottom right), indicative of a connective tissue phenotype, were detected in the meninges near the cortex, but not in the POA neuropil. B, Males had more mast cells than females on E20, P0, and P7, the critical period for sexual differentiation following staining for toluidine blue. Mast cell numbers significantly increased until P7 and decreased thereafter in both sexes with no further sex differences. C, Counts of 5-HT-positive mast cells in the POA on P2 corroborated toluidine blue staining counts in $\boldsymbol{B}$, with males having significantly more mast cells than females. D, Schematic of mast cell location in the forebrain (green circles). Mast cells in the POA are situated in both the neuropil and leptomeninges and additional mast cells are located in the velum interpositum adjacent to the hippocampus. $\boldsymbol{E}, \boldsymbol{F}$, Treatment of females on P0 -P1 with a masculinizing dose of estradiol increased (E) the total number of P0A mast cells (full bar graph) and the percentage of degranulated mast cells (shaded portion of bar graph shows number of degranulated cells) and $(\boldsymbol{F})$ the number of mast cells in the neuropil (shaded bars) versus the meninges on P4. G, On E20, during the testicular androgen surge in males, males had a higher percentage of degranulated mast cells than females (shaded bars depict number of degranulated cells). Data presented as mean $\pm S E M$. ${ }^{*} p<0.05$,

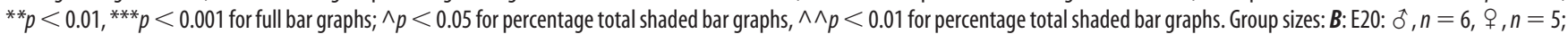

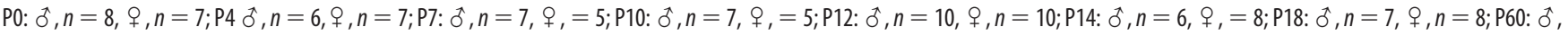

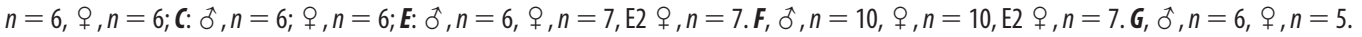



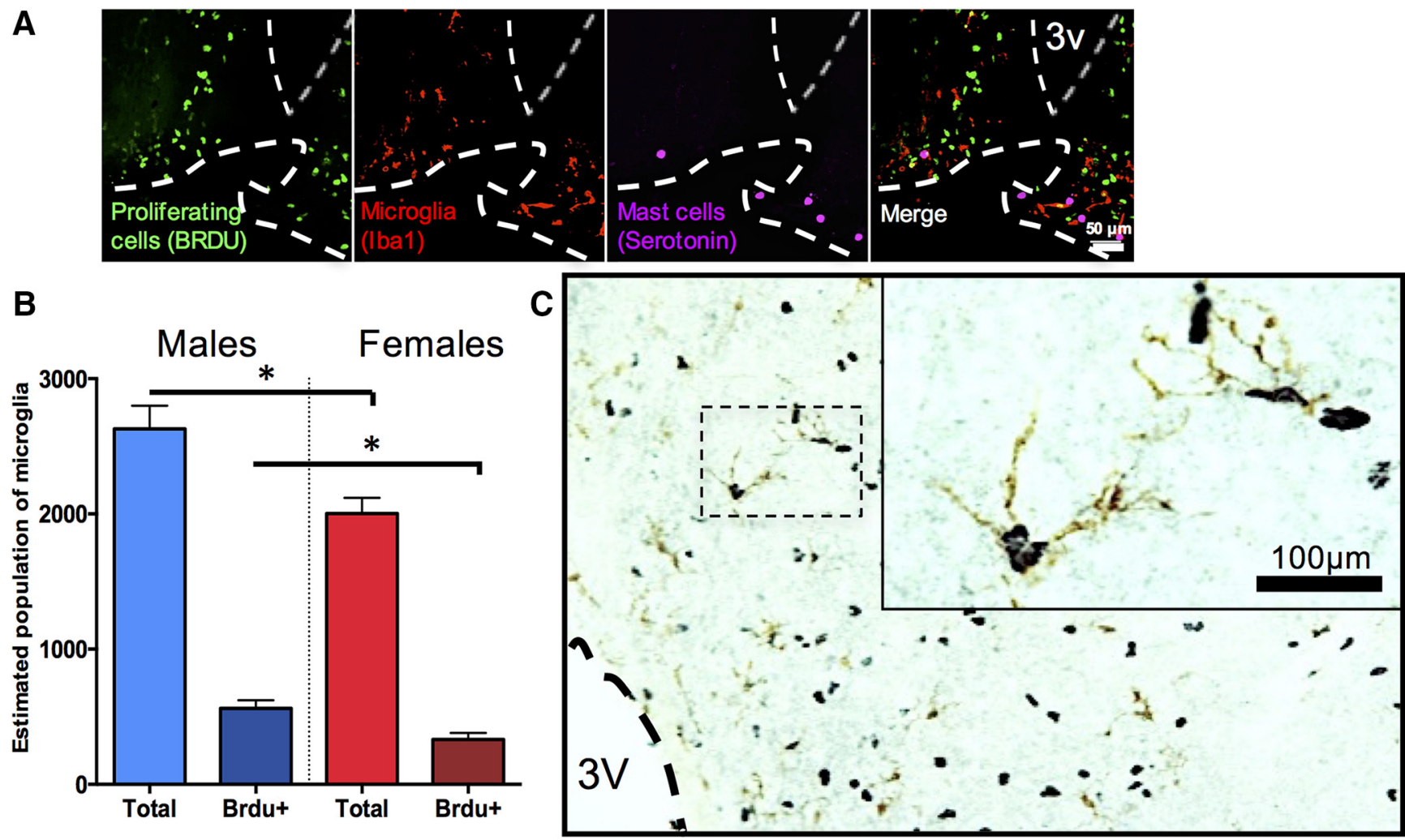

$\mathbf{D}$
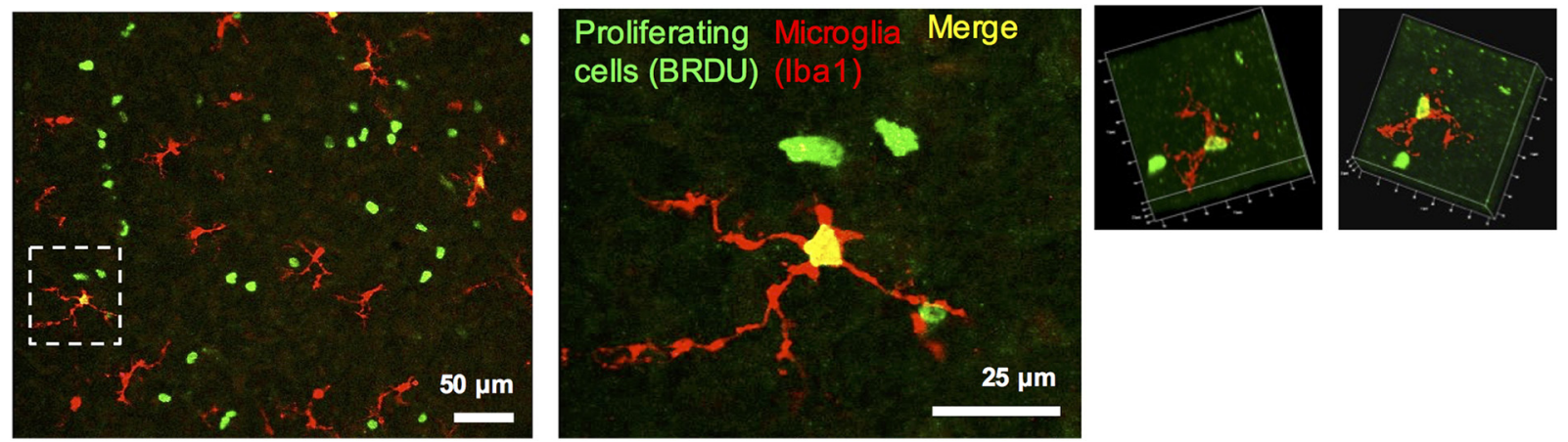

Figure 2. Mast cell and microglial proliferation in the developing POA. A, Labeling of proliferating cells (green, BrdU labeled), microglia (red, lba1 labeled), mast cells (purple, 5-HT labeled), and merged images (right) in the POA of the newborn animal on PO (dotted white lines indicate third ventricle and leptomeninges. There was no evidence of mast cell proliferation in the neonatal POA. $B$, Males had more microglia than females in the POA on P2. Although there were no mast cells that colabeled with BrdU in any group (Fig. 1H), Iba1-positive microglia colocalize with BrdU in the POA on P2, indicating microglial proliferation, and males have higher numbers of proliferating microglia than females. C, Representative image of IHC to double label microglia (Iba1 stained with DAB; brown) and proliferating cells (BrdU stained with Ni-DAB; black) in the POA on P3 ( $3 \mathrm{~V}=$ third ventricle). D, Representative images and Z-stack of immunofluorescently stained BrdU-positive (green) and Iba1-positive (red) cells showing colocalization. Counts of proliferating microglia were performed on DAB-stained tissue as seen in Cand colocalization confirmed via confocal imaging (D). ${ }^{*} p<0.05$. Group sizes: $A: n=4 /$ group. $\boldsymbol{B}, \hat{0}, n=11 ;$;,$n=8$.

0.04739, $p=0.8304$; Fig. $3 E)$ or PGD2 $\left(F_{\text {treat }(1,6)}=2.924, p=\right.$ 0.107 Fig. $3 F)$.

Microglia number and morphology are responsive to mast cell signaling

Mast cells are frequent partners with microglia, the primary immunocompetent cells of the brain (Aloisi, 2001; Silver and Curley, 2013). Microglia are emerging as important guides of developmental plasticity ( $\mathrm{Wu}$ et al., 2015), including a role in establishing sex differences in the POA (Lenz et al., 2013). Microglia in the neonatal male POA are more numerous, are more ameboid in shape, proliferate at a higher rate (Fig. $2 B-D$ ), and produce more PGE2 than the highly ramified microglia of females (Lenz et al., 2013). Therefore, assessing microglial mor- phology following mast cell manipulations is an excellent readout for downstream masculinization of the POA.

To determine whether mast cells communicate with microglia to establish this sex difference, we used a rapid-acting pharmacological strategy to stimulate mast cell degranulation, by infusing compound $48 / 80$, a potent and validated mast cell secretagogue (Chatterjea et al., 2012; Nautiyal et al., 2012; Chikahisa et al., 2013), directly into the brain of newborn females on the first $2 \mathrm{~d}$ of postnatal life. We subsequently assessed microglia morphology in the POA at P2. Compound 48/80 significantly increased mast cell degranulation in the POA $\left(t_{(7)}=3.214, p=0.0148\right.$; full bars indicate total number of mast cells, shaded bars indicate number of degranulated mast cells; Fig. $4 A$ ) and led to rapid increases in histamine turnover in the POA $\left(t_{(8)}=6.185, p=\right.$ 
A

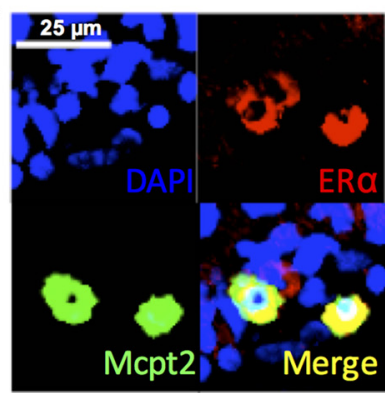

B

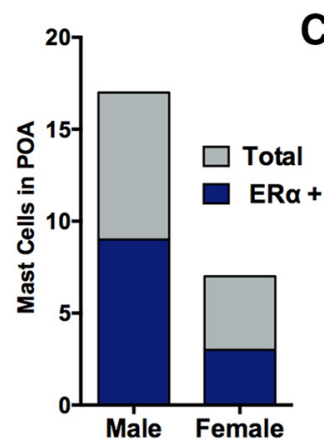

C

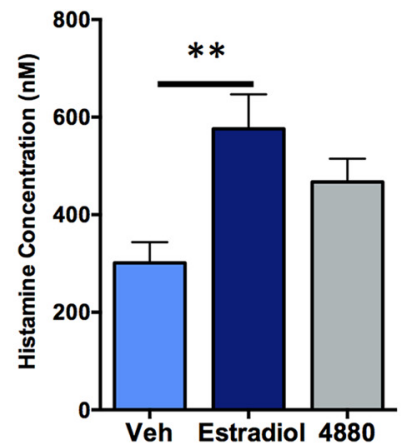

D

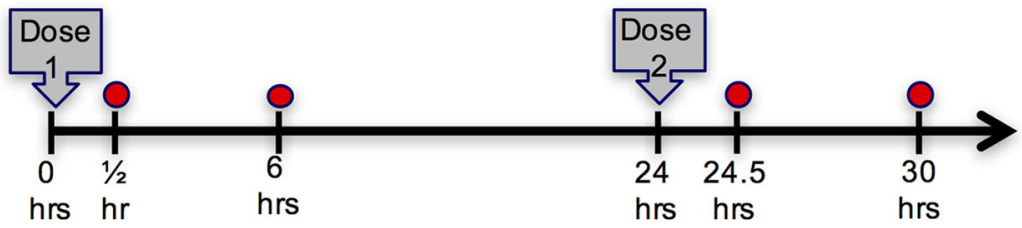

Measured $\mathrm{PGE}_{2}$ and $\mathrm{PGD}_{2}$ in mast cell media

E

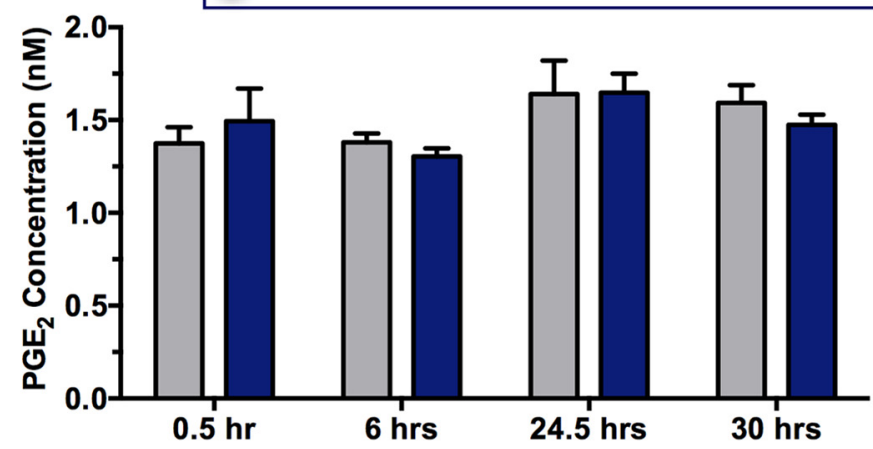

$\mathbf{F}$

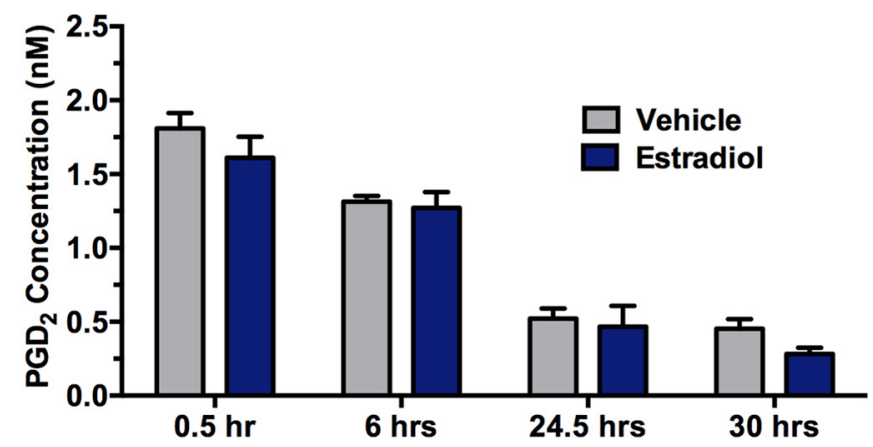

Figure 3. Estradiol effects on mast cell degranulation. $A, B$, Approximately half of POA mast cells stained positively for mast cell protease 2 (Mcpt2) antiserum also stained positive for estrogen receptor $\alpha$ in males and females. C, Treatment of primary cultured mast cells with estradiol increased histamine release to the same extent as the mast cell secretagogue compound $48 / 80$ (4880). $\boldsymbol{D}$, Primary mast cells cultured from the brain were treated with estradiol and measured for concentration of PGE2 $(\boldsymbol{E})$ and PGD2 $(\boldsymbol{F}) 0.5,6,24.5$, and $30 \mathrm{~h}$ after initial treatment, but the concentration of the prostaglandins did not increase at any time point. Estradiol was given a second time $24 \mathrm{~h}$ after initial treatment to the 24.5 and $30 \mathrm{~h}$ samples and still did not evoke PGE2 or PGD2 release from

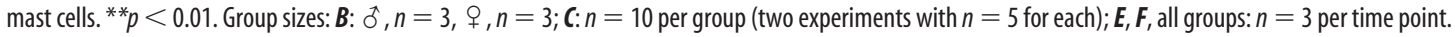

0.0003; Fig. 4B). In vivo, intracerebroventricular infusion of compound 48/80 did not alter mast cell degranulation in the spleen (Fig. 4C), confirming that effects were restricted to the CNS.

Next, we replicated our previous finding of a significant sex difference in the percentage of ameboid-shaped microglia in control animals. Additionally, we now observed that stimulating mast cell degranulation in females with central infusion of compound $48 / 80$ resulted in a complete sex reversal by increasing the percentage of amoeboid microglia to male levels $\left(F_{(2,15)}=12.44\right.$, $p=0.0007$; Fig. $4 D, E)$. To determine whether masculinization cannot only be induced by mast cell degranulation in females, but also prevented by mast cell inhibition in males, we used a prenatal treatment regimen with the Food and Drug Administrationapproved mast cell stabilizer ketotifen and assessed mast cell and microglia endpoints postnatally. In utero exposure to ketotifen via maternal drinking water decreased the percentage of degranulated mast cells in the POA of offspring (Fig. 4F) and also reduced the percentage of ameboid shaped microglia in males (Fig. $4 G$ ), thus dampening masculinization.

Sexual behavior in adulthood is programmed by early life mast cells

To determine whether the impact of greater numbers and more active mast cells on microglial morphology also influences early 
A

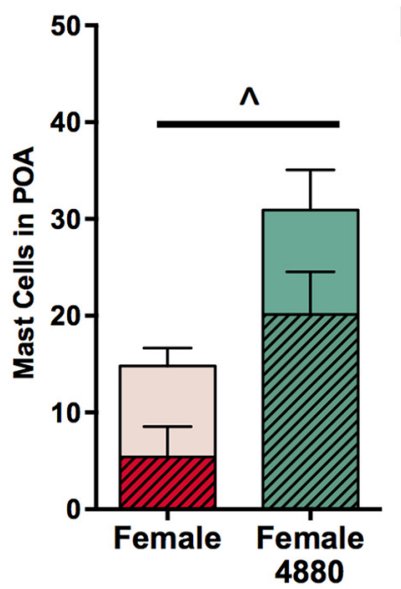

B

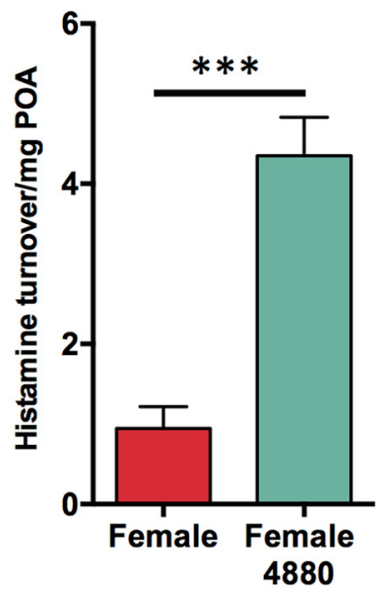

C

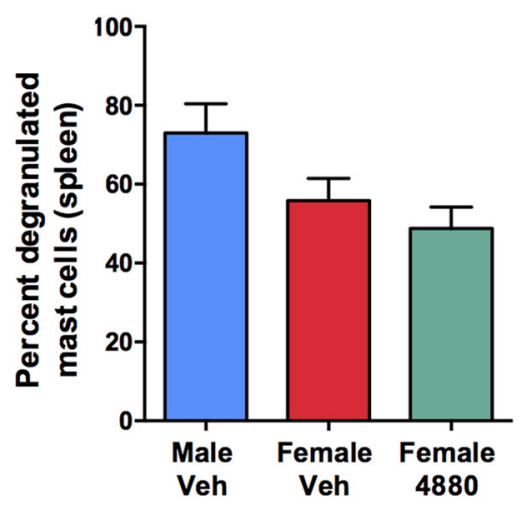

D

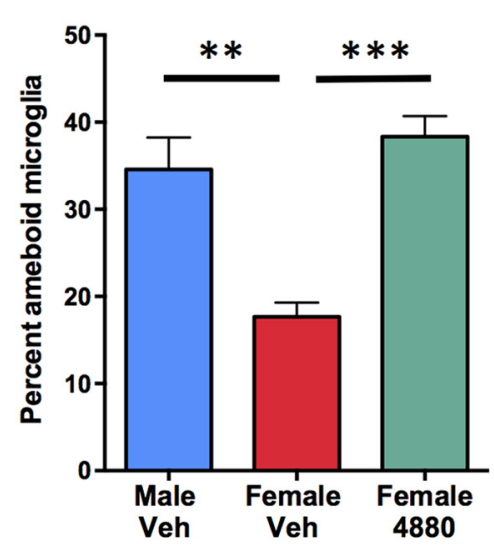

E
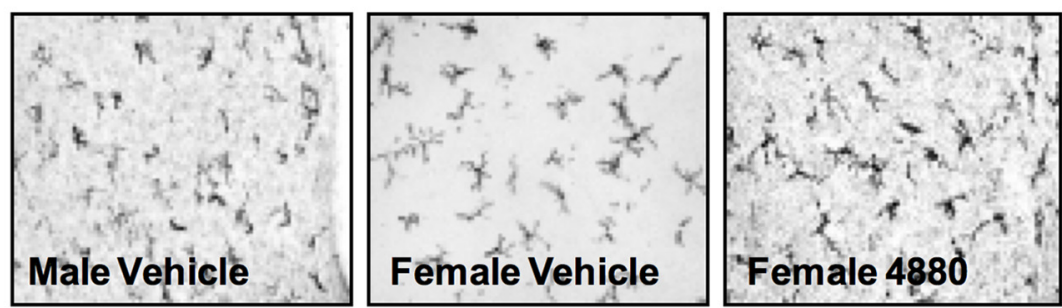

F

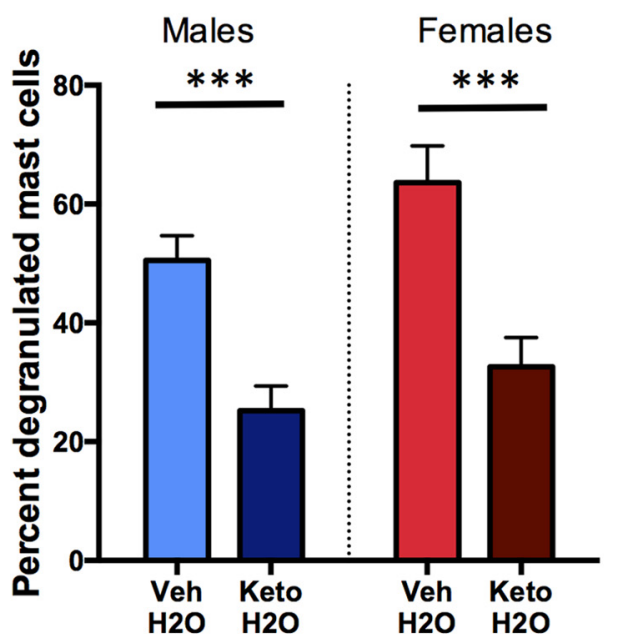

G

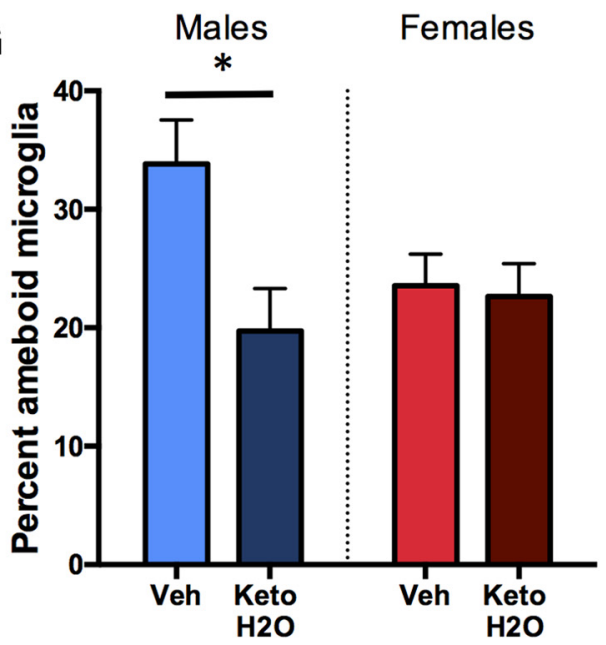

Figure 4. Confirmation of central versus peripheral mast cell manipulations and effects of mast cell manipulations on microglia. $A, B$, Compound 48/80 treatment in vivo (intracerebroventricularly) led to significant increases in percentage of degranulated mast cells in the POA of females on P2 (full bars indicate total number of mast cells, shaded bars indicate number of degranulated mast cells $(\boldsymbol{A})$, as well as increased histamine turnover in the POA as measured by LC-MS/MS (B). $\boldsymbol{C}$, Treatment with compound 48/80 (4880) did not change the proportion of degranulated mast cells in the spleen. $\boldsymbol{D}, \boldsymbol{E}$, Treatment of females with the mast-cell-degranulating agent compound 48/80 increased the proportion of microglia in an ameboid state in females to male levels. $\boldsymbol{F}, \mathbf{G}$, Treatment of maternal dams with the mast cell stabilizer ketotifen (keto) in their drinking water led to significant decreases in the percentage of degranulated mast cells in the POA of offspring of both sexes $(\boldsymbol{F})$ and decreased the proportion of microglia in the ameboid state in males to the level seen in females $(\boldsymbol{G})$.

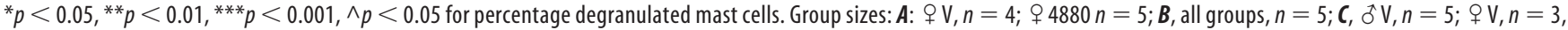

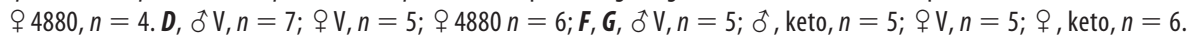

life programming of male-typical copulatory behavior, newborn female pups were treated with the mast cell stimulator compound $48 / 80$ and male and female control pups were treated with saline vehicle on $\mathrm{P} 0-\mathrm{P} 1$. Pups were then grown to adulthood, gonadectomized, implanted with testosterone capsules to provide adult male-typical hormone levels, and assessed for their motivation (latency) and execution (mount rate, ejaculation frequency) of masculine copulatory behavior with a sexually receptive female. The first trial familiarized animals to the test paradigm, whereas the second trial a week later was used for assessment of behavior. 
Neonatal treatment with compound $48 / 80$ masculinized the adult behavior of females because they started mounting more quickly $\left(F_{(2,35)}=5.12, p=0.011\right.$, ô $\mathrm{V}-q \mathrm{~V} \operatorname{HSD} p=0.017$; $q \mathrm{~V}-q 4880$ HSD: $p=0.023$; Fig. $6 A$ ) and more often (MannWhitney $U=20, p=0.013$; Fig. $6 B$ ) compared with female controls, such that their overall performance was equivalent to males.

We next sought to determine the converse of the above experiments that demonstrate that mast cell activation in females is sufficient to induce masculinization specifically to show that mast cell inhibition prevents masculinization in males, which largely occurs prenatally. Pregnant dams were again administered the mast-cell-stabilizing drug ketotifen in their drinking water. There was no effect of prenatal ketotifen exposure on the latency of adult male offspring to mount sexually receptive females $\left(F_{\text {treat (3.49) }}=2.219 p=0.099\right.$; Fig. $\left.6 C\right)$ but the mount rate was significantly reduced in ketotifen-exposed males compared with controls (Mann-Whitney $U=34, p=0.013$; Fig. $6 D$ ). These same males took longer to ejaculate (MannWhitney $U=130.5, p=0.0135$; Fig. $6 E)$ and ejaculated less frequently (Mann-Whitney $U=37.5 p=0.021$; Fig. $6 F$ ) compared with non-ketotifen-exposed males. Therefore, the prenatal activation of mast cells contributes to sex-specific programming of later life reproductive behavior. Because ketotifen was given to pregnant dams, the effects could extend beyond the fetal brain and include the fetal spleen and gut, placenta or maternal physiology.

\section{Mechanisms of mast-cell-mediated synaptic patterning:}

Neurons in the POA exhibit a marked sex difference in that males have two to three times the density of dendritic spine synapses and higher levels of the dendritic spine marker protein spinophilin compared with females (Wright and McCarthy, 2009; Lenz et al., 2013). Both measures positively correlate with motivation for sex and frequency of male-typical mounting (Amateau and McCarthy, 2004). To establish whether the effects of mast cells on neuronal dendritic spines are local to the POA and depend on microglia, we generated sex-specific primary POA mixed cultures and removed microglia from a subset and mast cells from all. Separately, isolated mast cell cultures, which were validated as containing no other cell types (Fig. $5 \mathrm{~A}$ ), were treated with compound $48 / 80$ to generate conditioned medium, which was then applied to the primary POA cultures. Two days later, spine-like protrusions on neurites were quantified. Conditioned medium from stimulated mast cells increased the density of spine-like protrusions on female POA neurons, but only if microglia were present in the cultures $\left(F_{(2,9)}=11.22, p=0.0036\right.$; Fig. $\left.5 B\right)$. Direct treatment of neuronal cultures with the compound $48 / 80$ had no effect, confirming the role of mast cells and indicating no nonspecific effects of compound $48 / 80$ on neurons or astrocytes $\left(t_{(16)}=0.889 ; p=0.38\right.$; Fig. 5C).

Given that mast cells release a spinogenic factor that is not PGE2 (Fig. 2D,E), that estradiol increases histamine release from mast cells in vitro (Fig. 2C), and that microglia are necessary for propagating the mast-cell-derived signal (Fig. $5 B$ ), we hypothesized that histamine is the spinogenic factor released by mast cells in response to estradiol. Histamine then triggers microglia to produce PGE2 and PGE2 signals for spine formation (Fig. 7 C). Consistent with our hypothesized model, we first found that microglia in the POA stain positive for histamine receptors type 1 and 4 (Fig. 8A). Next, we found that media from brain mast cells stimulated with estradiol increased spine-like protrusions on cultured POA neurons, but not if the primary cultures were pretreated with antagonists for $\mathrm{H} 1$ and $\mathrm{H} 4$ type histamine receptors
$\left(F_{(4,29)}=7.717, p=0.001\right.$, HSD $p=0.024$; Fig. $8 B$, top $)$. Moreover, the media from mast cells stimulated with estradiol did not increase spine-like protrusions when microglia were removed from the primary cultures and estradiol given directly to neuronal cultures devoid of microglia had no effect. Likewise, media from primary brain mast cells stimulated with estradiol triggered a twofold increase in PGE2 levels in mixed microglia/neuronal cultures, but not if cultures were pretreated with $\mathrm{H} 1$ and $\mathrm{H} 4$ receptor antagonists or if the media was added to POA cultures in which the microglia were depleted $\left(F_{(4,29)}=43.82, p<0.001\right.$, $\mathrm{H} 1 / \mathrm{H} 4$ HSD $p<0.001$; Figure $8 B$, bottom), confirming that mast-cell-derived histamine acts on microglia to induce PGE2, which then induces masculinization of dendritic spine density on POA neurons.

Previously, we demonstrated that PGE2 induces spine-like processes on cultured POA neurons (Amateau and McCarthy, 2004) and, here, we determined that histamine does the same $\left(F_{(4,29)}=66.09 p<0.001\right.$, Tukey's HSD $p<0.001$; Fig. $8 C$, top $)$ by increasing PGE2 levels $\left(F_{(4,29)}=12.43 p<0.001\right.$, Tukey's HSD $p<0.001$; Fig. $8 C$, bottom). If microglia were removed from POA cultures, then histamine had no stimulatory effect on dendritic spine density (HSD $p<0.001$; Fig. $8 B$, top) or PGE2 levels (HSD $p=0.027$; Fig. $8 B$, bottom). The elevations in PGE2 content by histamine or estradiol-stimulated mast cell media could be recapitulated on isolated microglial cultures, but not if pretreated with $\mathrm{H} 1$ and $\mathrm{H} 4$ histamine receptor antagonists $\left(F_{(6,44)}=27.82 p<0.001\right.$, Tukey's HSD $p<0.001$; Fig. $\left.8 D\right)$. Direct administration of estradiol onto POA cultures with microglia stimulated some PGE2 production, but did not fully reestablish the elevations in PGE2 content observed in the mast-cell media that was stimulated with estradiol (Fig. 8B). Although microglia are therefore the primary source of PGE2 production in response to mast-cell-derived histamine, there is also evidence of residual production of PGE2 by the neurons themselves (Fig. $8 B$, bottom), but it is nevertheless insufficient to significantly elevate spine formation (Fig. 8B, top). Levels of PGE2 and dendritic spine density were positively correlated across all groups in the in vitro histamine experiment $\left(R^{2}=0.318, p=0.001\right.$; Fig. $\left.8 C\right)$, further confirming the spinogenic effect of PGE2.

Finally, confirming our observed effects of histamine on PGE2 and dendritic spines in the POA in vivo, we found that treating newborn female pups with antagonists for histamine receptors types 1 and 4 reduced PGE2 production in the POA $\left[F_{(2,22)}=\right.$ $13.08 p=0.0002 \mathrm{HSD}$ (males vs females) $p=0.0255$; (female vehicle vs female + histamine receptor antagonists) $p=0.0 .255$; Fig. $7 \mathrm{~A}]$. In addition, infusing newborn females intracerebroventricularly with the mast-cell-degranulating agent compound 48/80 led to increased levels of the dendritic spine marker spinophilin in the POA and cotreatment with $\mathrm{H} 1$ and $\mathrm{H} 4$ type histamine receptor antagonists prevented the masculinizing effects of mast cell activation $\left(F_{(4,32)}=7.16 p<0.001\right.$, Tukey's HSD $p<$ 0.001 ; Tukey's HSD for male vs. female and female vehicle vs female + compound 48/80, $p<0.05$; Fig. $7 B$ ). Overall, these data indicate estradiol acts in the developing POA to directly degranulate mast cells and stimulate the release of histamine; this mastcell-derived histamine activates microglia and spurs microglial production and release of PGE2; PGE2, in turn, promotes maletypical synaptic patterning on POA neurons, which directs maletypical copulatory behavior in adulthood (Fig. 7C).

\section{Discussion}

Steroid hormones are the principal drivers of brain sexual differentiation. There has been a long-standing assumption that hor- 

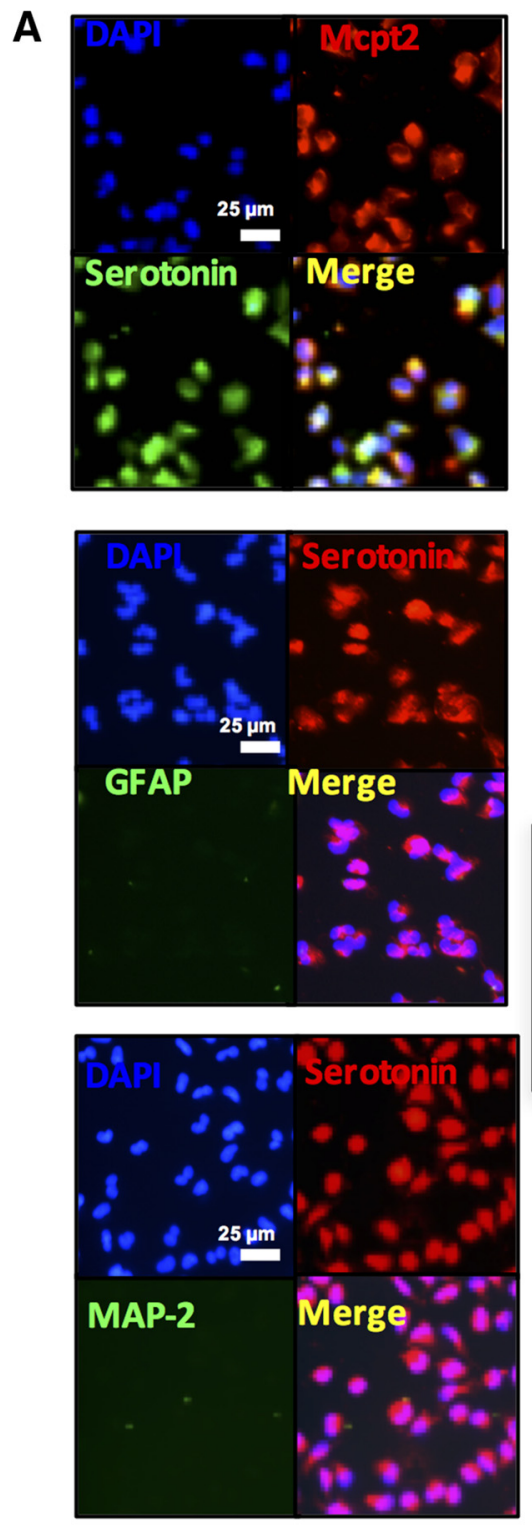

B
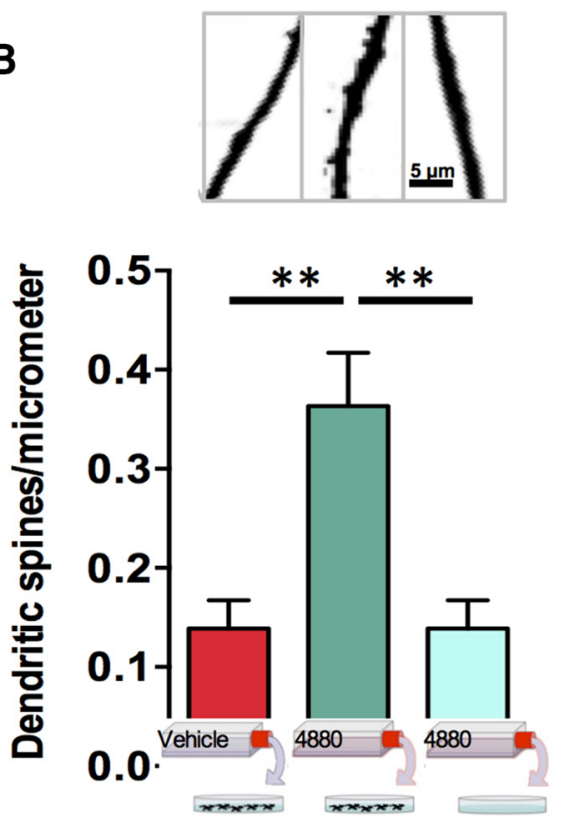
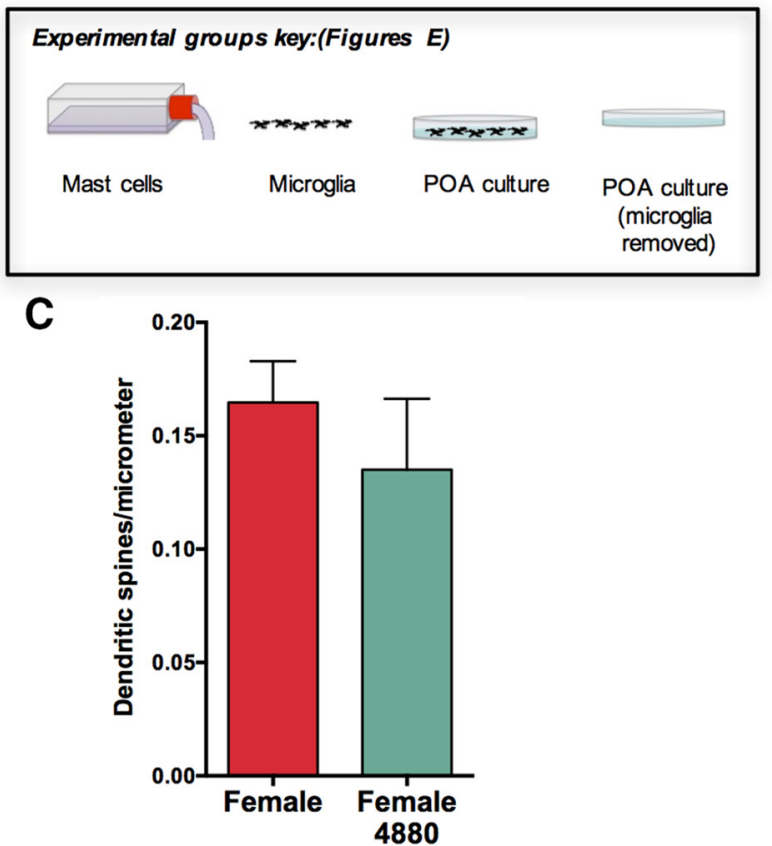

Figure 5. Mast-cell-induced masculinization of POA dendritic spines in vitro. $\boldsymbol{A}$, Validation of pure mast cell primary cultures. All DAPI-positive cells (from primary mast cell cultures stain positive for mast cell protease-2 (Mcpt2) and 5-HT (top), but do not show any staining for GFAP to mark astrocytes (middle) or MAP-2 to mark neurons (bottom). The bottom right of each panel is the merged image of costaining. $\boldsymbol{B}$, Density of dendritic spine-like protrusions on female primary P0A neurons increased after exposure to conditioned medium from mast cells stimulated with compound $48 / 80$, but prior removal of the microglia prevented this increase. C, Compound $48 / 80$ had no effects on the density of dendritic spines when given directly to the neurons. This contrasts with the spinogenic effects of compound $48 / 80$ when it is first administered to mast cells and the mast-cell-conditioned media is then applied to the neurons (B). ${ }^{* *} p<0.01$. B, All groups, $n=6$. C, All groups, $n=14$.

mones act largely upon neurons because they express steroid receptors at high levels. We here demonstrate that sex-specific organization of the POA and resultant male-typical sexual behavior depends upon a surprising cellular player, the mast cell. Mast cells populate the brains of many species, including humans (Georgin-Lavialle et al., 2016), but the possibility that mast cells are important to human brain development was discounted due to their sparseness. This warrants revisiting given our observation that a very small number of mast cells powerfully shape lifelong sex-specific endpoints in brain morphology and behavior.
The mechanism by which PGE2 stimulates dendritic spine synapse formation in the POA is known and involves EP2 and 4 receptors, activation of protein kinase A, and AMPA-type glutamate receptors (Wright and McCarthy, 2009; Lenz et al., 2011). Excitatory afferent input to the POA from the medial amygdala integrates olfactory stimuli from sexually receptive females (Baum and Everitt, 1992). Increased glutamatergic transmission in the POA is a prerequisite for male mating behavior (Dominguez et al., 2006). Therefore, the increased density of excitatory dendritic spine synapses on POA neurons in males ensures that 
A

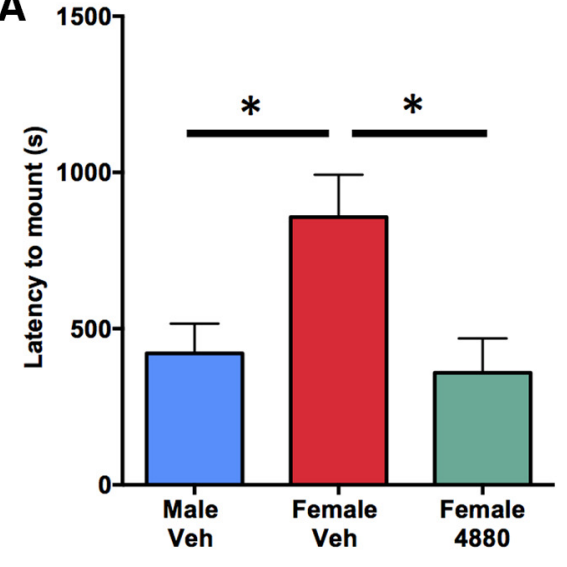

Males Females

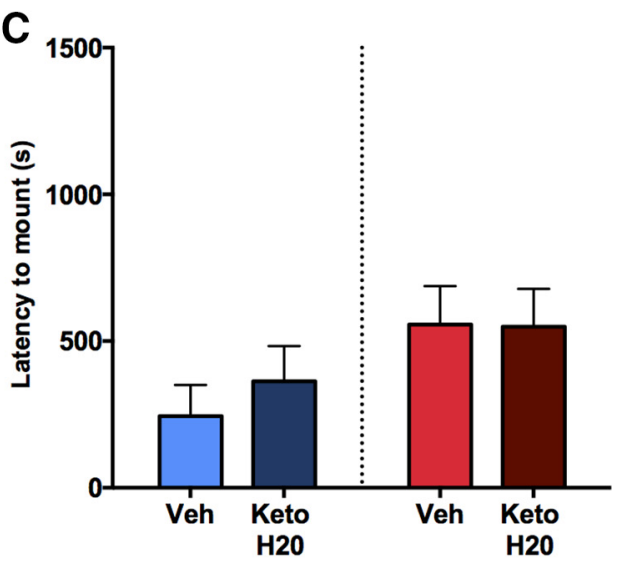

B
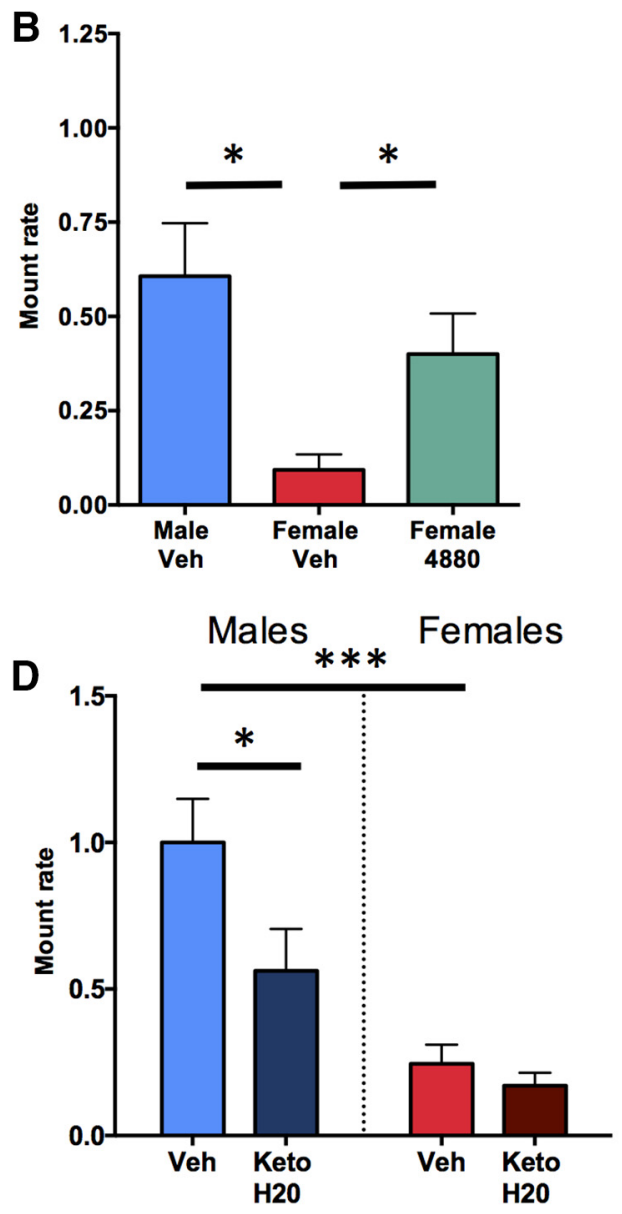

E

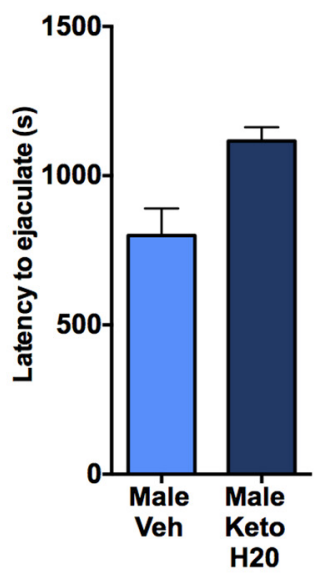

F

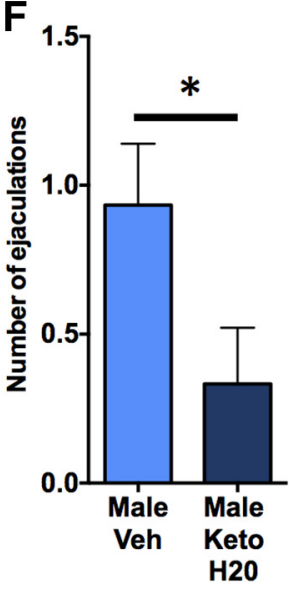

Figure 6. Manipulation of mast cells perinatally modifies male-typical reproductive behaviors in adulthood. $\boldsymbol{A}-\boldsymbol{D}$, Females treated postnatally with compound $48 / 80$ (4880) and then given testosterone as adults began mounting sexually receptive females more quickly and mounted more frequently than control females. $C$, Although adult males treated perinatally with the mast cell stabilizer ketotifen (keto) (given via the pregnant dam's drinking water between gestational day 17 and P7) did not delay in mounting (C), they nonetheless mounted less frequently (D), reached their first ejaculation later $(\boldsymbol{E})$, and ejaculated fewer times $(\boldsymbol{F})$ than control males. Data are presented as mean \pm SEM. \#Trend $0.05 \leq 32 p<0.1 .{ }^{*} p<0.05,{ }^{* *} p<0.01$, ${ }^{* * *} p<0.001$. Group

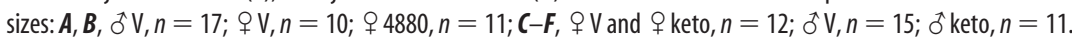

sufficient excitation is achieved to supercede the inhibitory threshold for mating behavior.

Our data indicate that mast cells basally contribute to the masculinization process in males because mast cell inhibition decreased male-typical sexual behavior in adulthood. Likewise, pharmacologically induced increases in mast cell activation in females affects female sexual differentiation, shifting females toward a male-typical organization of the POA that is life-long and corresponds with increases in male-typical sociosexual behaviors. We further identified histamine as a mast-cellderived mediator that induces masculinization of microglia and dendritic spine endpoints and likely affects the masculinization process by stimulating microglia to release PGE2, which we have previously identified as the major molecular signal driving masculinization of the POA and male-typical sexual behavior (Amateau and McCarthy, 2004; Wright and 
A

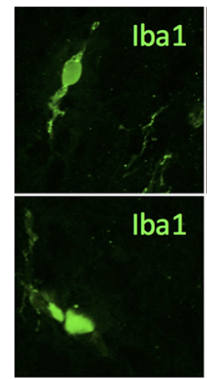

B
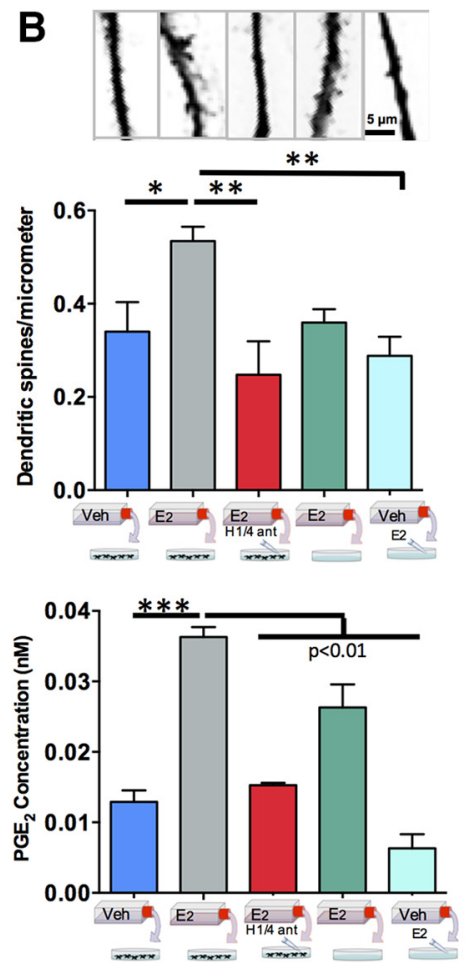

D

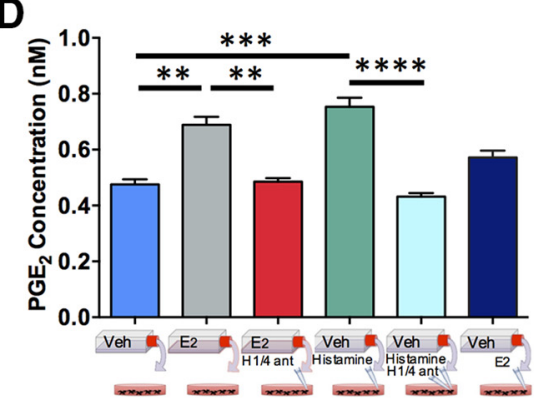

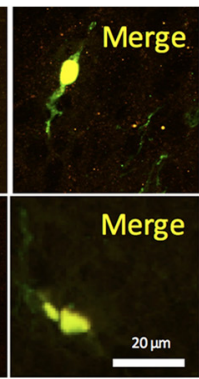
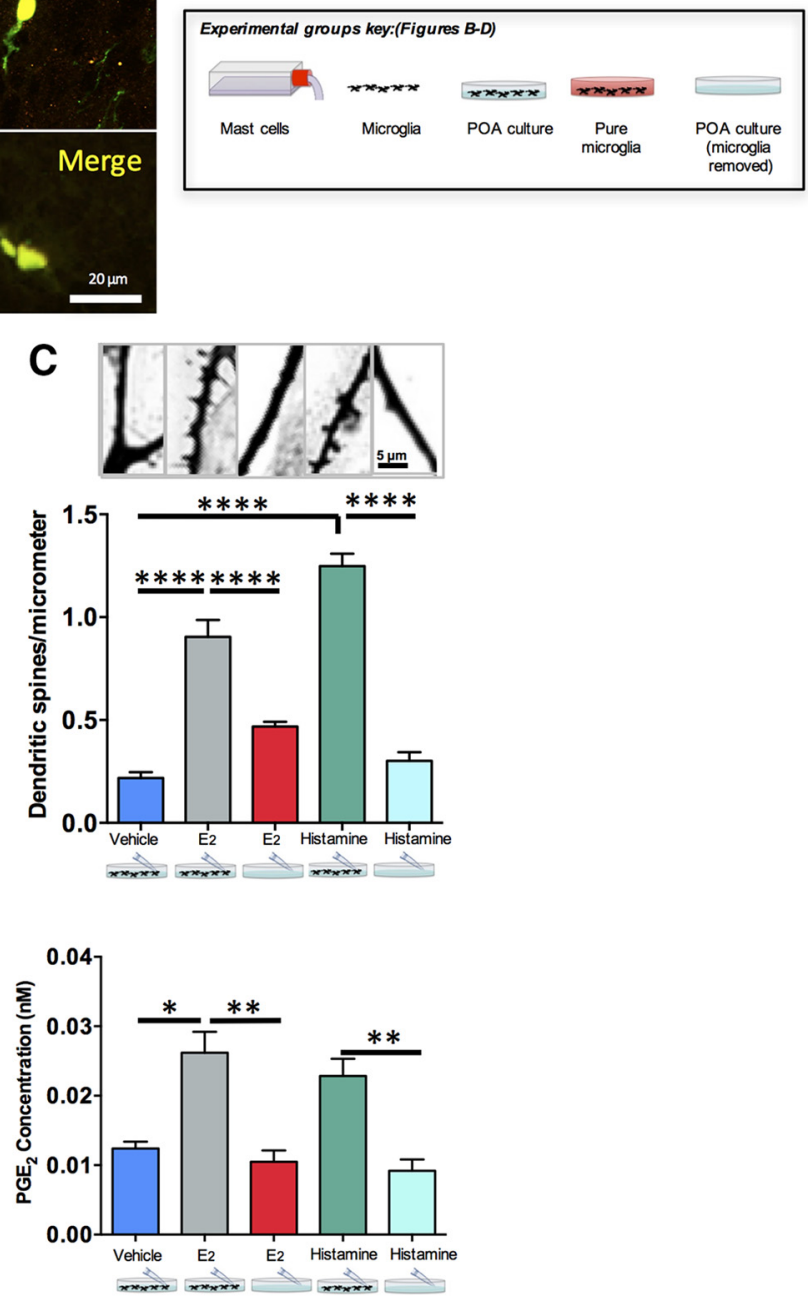

$\mathbf{E}$

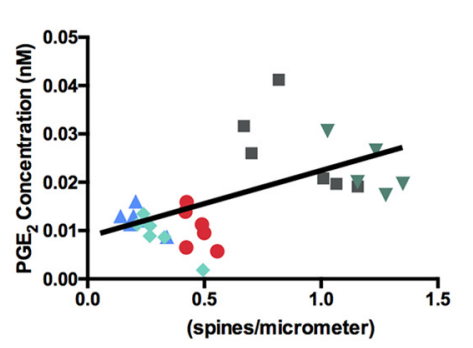

Figure 7. Mechanisms of mast-cell-induced masculinization of POA dendritic spines in vitro. $\boldsymbol{A}$, Iba1 microglia within the POA costain for histamine receptors type 4 (top) and type 1 (bottom). $\boldsymbol{B}$, Treatment with conditioned media from estradiol-stimulated mast cells increased the density of dendritic spines (top graph) and PGE2 concentration (bottom graph) and prior removal of microglia or inhibition of $\mathrm{H} 1$ and $\mathrm{H} 4$ histamine receptors prevented these increases. $C$, Administration of histamine directly onto primary POA cultures also increased the density of dendritic spines (top graph) and PGE2 concentration (bottom graph) to levels equivalent to that induced by estradiol treatment and, again, prior removal of microglia prevented these increases. D, PGE2 concentration increased in microglia cultures after exposure to histamine or conditioned medium from mast cells stimulated with estradiol, but not after pretreatment with $\mathrm{H} 1$ and $\mathrm{H} 4$ histamine receptor antagonists (Ant). $E$, Dendritic spine levels positively correlate with PGE2 concentration in primary POA cultures treated with vehicle, estradiol, histamine, or in which microglia were removed from the cultures before addition of estradiol or histamine. Data are presented as mean $S E M .{ }^{*} p<0.05,{ }^{* *} p<0.01,{ }^{* * *} p<0.001,{ }^{* * * *} p<0.0001$. Group sizes: $\boldsymbol{A}$, all groups, $n=4 ; \boldsymbol{B}$, all groups, $n=6 ; \boldsymbol{C}$ and $\boldsymbol{E}$, all groups, $n=6 ; \boldsymbol{D}$, Veh, mast cells $+\mathrm{E} 2$, mast cells $+\mathrm{E} 2+$ histamine ant, and histamine, $n=8$; histamine + histamine ant, $n=7$, histamine and direct E2 treatment, $n=6$.

McCarthy, 2009; Lenz et al., 2013). Depending upon their microenvironment, mast cells synthesize and release a host of mediators in addition to histamine, including 5-HT, cytokines such as TNF- $\alpha$, IL-13, PGD2, and several proteases (Silver and Curley, 2013). These mediators may likewise contribute to the masculinization of the POA and warrant future inquiry.
Moreover, the impact of prenatal exposure to the mast cell stabilizer ketotifen is confounded by potential effects on maternal physiology, the fetal body, and the placenta. Although these may involve nonspecific effects, it remains possible that mast cells in these compartments also participate in sexual differentiation of the fetal brain. 
A

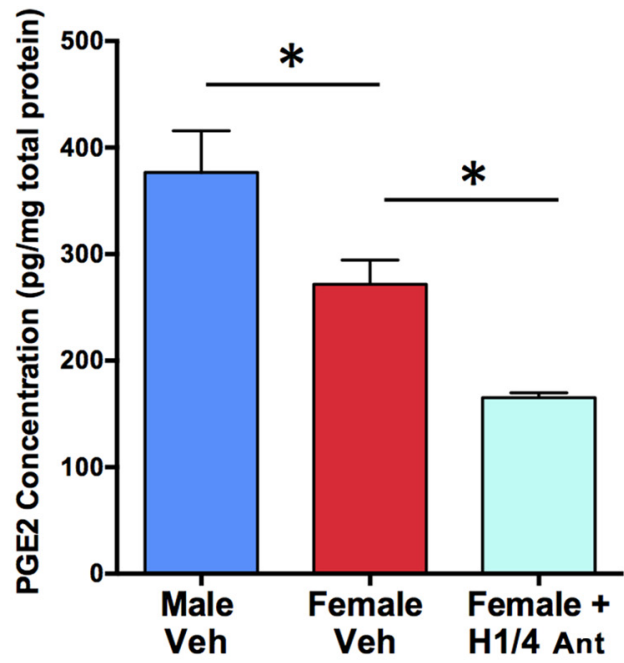

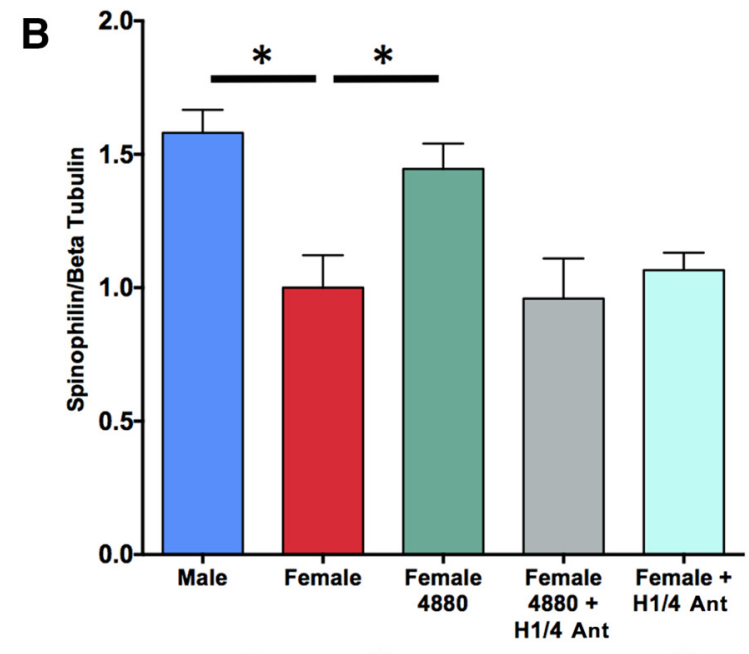

Spinophilin - - $--\vdots--\vdots-120 \mathrm{kDa})$

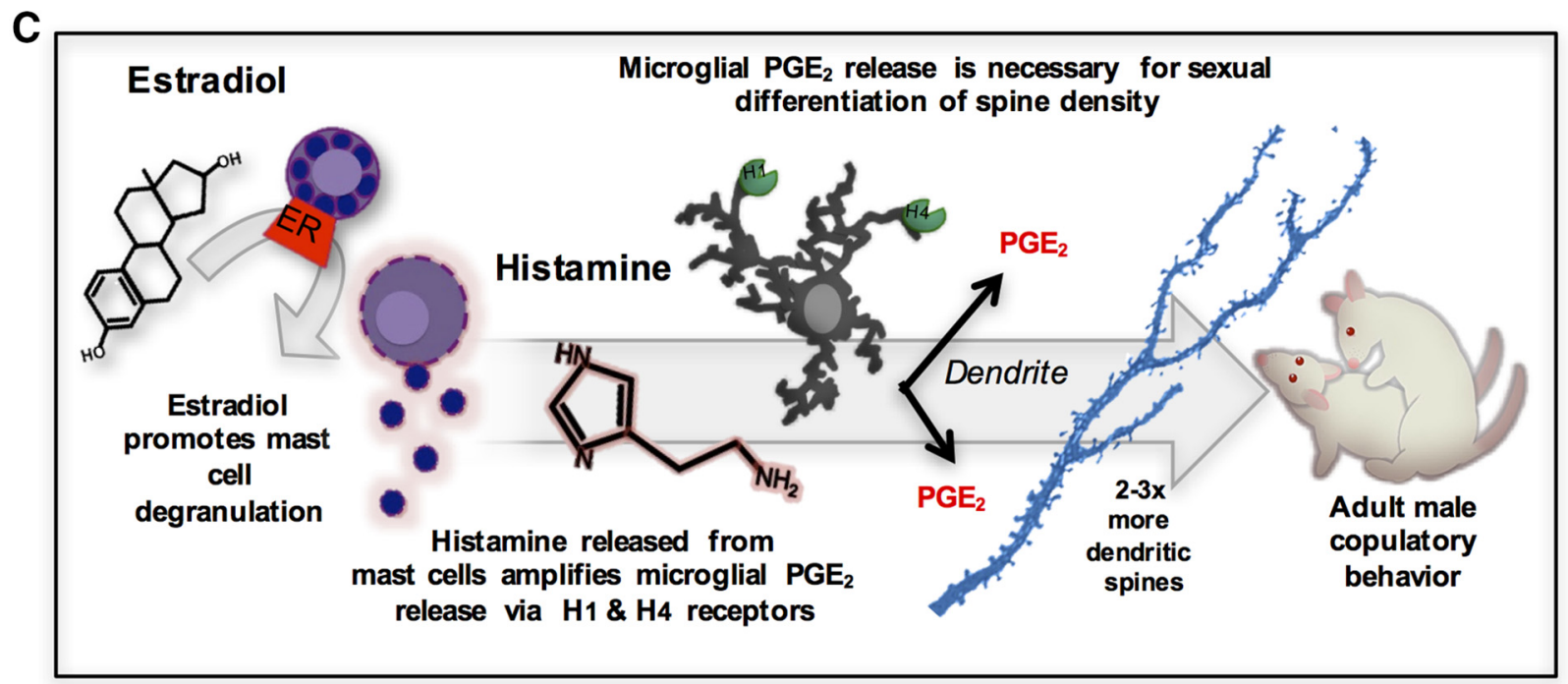

Figure 8. Effects of histamine receptor antagonism on PGE2 dendritic spine proteins in vivo and working model of mast cell effects on the masculinization of the POA. $A$, In vivo, the neonatal male POA showed higher PGE2 concentrations than female and treating females with histamine receptor $1 / 4$ antagonists (ant) further decreased PGE2 levels. $\boldsymbol{B}$, Treatment of neonatal females with compound 48/80 (4880) intracerebroventricularly led to increased spinophilin content in the POA and cotreatment of females with histamine receptor 1 and 4 antagonists prevented this increase $\left(F_{(4,32)}=7.16 p<0.001\right.$, Tukey's HSD $p<0.001$; Tukey's HSD for M-F and F-F4880 $\left.p<0.05\right]$, indicating that histamine receptor activation is necessary for the masculinizing effects of mast cell degranulation on dendritic spines to occur in vivo. C, Together, the current data suggest that estradiol acts on ER-in mast cells to stimulate mast cell degranulation and the release of histamine into the male POA during the critical period for sexual differentiation. Histamine binds to $\mathrm{H} 1$ and $\mathrm{H} 4$ type histamine receptors on microglia and stimulates microglia to release PGE2. Microglia-derived PGE2 stimulates the masculinization of dendritic spine patterning on POA neurons in early life that enables male-typical copulatory behavior in adulthood. ${ }^{*} p<0.05$. All immunoblots

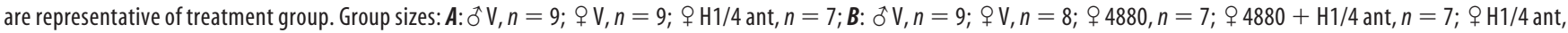
$n=6 .{ }^{*} p<0.05$.

Female brain development occurs in the absence of elevated levels of gonadal steroids and as a genetically programmed process would be predicted to occur along highly similar lines across individuals. Therefore, girls would be expected to show less variation in sex-typical behavior than boys, yet the opposite is true, with boys exhibiting narrower ranges of behavioral variability (Zucker and Bradley, 1995). This may have origins in culture and societal expectations, but may also have biological origins. Further, girls with congenital adrenal hyperplasia experience prenatal androgen exposure and exhibit masculinization of some psychosexual traits (Hines, 2011), but the degree of behavioral masculinization does not track linearly with genital virilization, which is hormone dependent, suggesting that factors other than hormones are at play. Our observation that mast cells are key players in normal masculinization but can also affect female brain development independently of steroids suggests that these small but potent cells may be a source of phenotypic variation in females. Many factors provoke mast cell degranulation, including allergic responses, mild inflammation, and minor injuries. These and other relatively innocuous events during pregnancy or in the early postnatal period could affect brain sexual differentiation by altering mast cell activity. The impact of mild perturbations would be predicted to be greater in females because it would be against a background of low mast cell activity compared with the high levels observed in males. Therefore, whereas the impact of estradiol on the developing POA likely involves multiple signal- 
ing pathways and cell types beyond mast cells, our results are consistent with an important role for mast cells as an additional and heretofore unknown contributor to sex differences in behavior. A sex difference in the transcriptome of peripheral mast cells was recently identified (Mackey et al., 2016), which, if also true in the CNS, could further contribute to sex-specific impacts of prenatal allergic or inflammatory exposure.

Our findings highlight crosstalk between immune cells in the brain. Developing male rat brains have more microglia and mast cells and higher levels of inflammatory signaling molecules such as PGE2. In humans, glial and inflammatory genes are more highly expressed in the fetal male brain (Werling et al., 2016), so it is hypothesized that inflammatory mediators may serve the normal masculinization process in our species as well. Moreover, higher basal inflammatory signaling in the male brain may make males more vulnerable to altered behavioral development following inflammogenic perturbations early in life, including early life infection and stress (Schwarz and Bilbo, 2012). A heightened basal innate immune cell presence in the male brain may also increase male vulnerability to neurodevelopmental disorders that include neonatal inflammation and infection among their risk factors, including autism, schizophrenia, and attention deficit hyperactivity disorder (Braunschweig and Van de Water, 2012; Suzuki et al., 2013; Estes and McAllister, 2015; Instanes et al., 2017). Both autism and schizophrenia are associated with increased immune-associated gene expression and inflammatory signaling in the brain (Braunschweig and Van de Water, 2012; Suzuki et al., 2013; Estes and McAllister, 2015; Werling et al., 2016; Instanes et al., 2017). Autism is diagnosed four times more frequently in males (Mandy et al., 2012; Schaafsma and Pfaff, 2014) and schizophrenia varies in onset, symptomology, and severity in men and women (Goldstein et al., 1994; Nopoulos et al., 1997; Abel et al., 2010). Males with autism show a shift toward hypermasculinized brain activity within sociocognitive brain networks, as well as a shift toward neurotypical female brain activity in sensorimotor networks, which demonstrates that shifts in sex differences in the brain are prevalent in the disorder (Floris et al., 2018). Additionally, fluid sexual orientation, transgender identity, and gender dysphoria are common in women with autism (Dewinter et al., 2017), again suggesting some mechanistic association between the risk factors for autism and the process of brain sexual differentiation. The POA is rarely considered in the context of these disorders, yet, in addition to its role in mating behavior, it is a crucial brain region for bonding, social recognition, and caregiving (Ferguson et al., 2001; Insel and Young, 2001; Champagne et al., 2006). Our findings uncover mast cells as a novel source of sex-specific variability in development that may contribute both to normal sex differences and to gender biases in risk for psychiatric and neurological disorders (Theoharides et al., 2012; McCarthy et al., 2017).

\section{References}

Abel KM, Drake R, Goldstein JM (2010) Sex differences in schizophrenia. Int Rev Psychiatry 22:417-428. CrossRef Medline

Aloisi F (2001) Immune function of microglia. Glia 36:165-179. CrossRef Medline

Amateau SK, McCarthy MM (2004) Induction of PGE2 by estradiol mediates developmental masculinization of sex behavior. Nat Neurosci 7:643650. CrossRef Medline

Baum MJ, Everitt BJ (1992) Increased expression of c-fos in the medial preoptic area after mating in male rats: role of afferent inputs from the medial amygdala and midbrain central tegmental field. Neuroscience 50:627646. CrossRef Medline

Braunschweig D, Van de Water J (2012) Maternal autoantibodies in autism. Arch Neurol 69:693-699. CrossRef Medline
Champagne FA, Weaver IC, Diorio J, Dymov S, Szyf M, Meaney MJ (2006) Maternal care associated with methylation of the estrogen receptoralphalb promoter and estrogen receptor-alpha expression in the medial preoptic area of female offspring. Endocrinology 147:2909-2915. CrossRef Medline

Chatterjea D, Wetzel A, Mack M, Engblom C, Allen J, Mora-Solano C, Paredes L, Balsells E, Martinov T (2012) Mast cell degranulation mediates compound 48/80-induced hyperalgesia in mice. Biochem Biophys Res Commun 425:237-243. CrossRef Medline

Chikahisa S, Kodama T, Soya A, Sagawa Y, Ishimaru Y, Séi H, Nishino S (2013) Histamine from brain resident MAST cells promotes wakefulness and modulates behavioral states. PLoS One 8:e78434. CrossRef Medline

Dewinter J, De Graaf H, Begeer S (2017) Sexual orientation, gender identity, and romatic relationships in adolescents and adults with autism spectrum disorder. J Autism Dev Disord 47:2927-2934. CrossRef Medline

Dominguez JM, Gil M, Hull EM (2006) Preoptic glutamate facilitates male sexual behavior. J Neurosci 26:1699-1703. CrossRef Medline

Estes ML, McAllister AK (2015) Immune mediators in the brain and peripheral tissues in autism spectrum disorder. Nat Rev Neurosci 16:469486. CrossRef Medline

Ferguson JN, Aldag JM, Insel TR, Young LJ (2001) Oxytocin in the medial amygdala is essential for social recognition in the mouse. J Neurosci 21 : 8278-8285. CrossRef Medline

Floris DL, Lai MC, Nath T, Milham MP, Di Martino A (2018) Networkspecific sex differentiation of intrinsic brain function in males with autism. Mol Autism 9:17. CrossRef Medline

Georgin-Lavialle S, et al. (2016) Mast cells' involvement in inflammation pathways linked to depression: evidence in mastocytosis. Mol Psychiatry 21:1511-1516. CrossRef Medline

Goldstein JM, Seidman LJ, Santangelo S, Knapp PH, Tsuang MT (1994) Are schizophrenic men at higher risk for developmental deficits than schizophrenic women? implications for adult neuropsychological functions. J Psychiatr Res 28:483-498. CrossRef Medline

Hines M (2011) Gender development and the human brain. Annu Rev Neurosci 34:69-88. CrossRef Medline

Hull EM, Meisel RL, Sachs BD (2002) Male sexual behavior. Horm Brain Behav 1:3-137.

Insel TR, Young LJ (2001) The neurobiology of attachment. Nat Rev Neurosci 2:129-136. CrossRef Medline

Instanes JT, Halmøy A, Engeland A, Haavik J, Furu K, Klungsøyr K (2017) Attention-deficit/hyperactivity disorder in offspring of mothers with inflammatory and immune system diseases. Biol Psychiatry 81:452-459. CrossRef Medline

Konkle AT, McCarthy MM (2011) Developmental time course of estradiol, testosterone, and dihydrotestosterone levels in discrete regions of male and female rat brain. Endocrinology 152:223-235. CrossRef Medline

Krishnaswamy G, Chi DS (2006) Mast cells: methods and protocols. Totowa, NJ: Humana.

Lenz KM, Nugent BM, Haliyur R, McCarthy MM (2013) Microglia are essential to masculinization of brain and behavior. J Neurosci 33:27612772. CrossRef Medline

Lenz KM, Wright CL, Martin RC, McCarthy MM (2011) Prostaglandin $\mathrm{E}_{2}$ regulates AMPA receptor phosphorylation and promotes membrane insertion in preoptic area neurons and glia during sexual differentiation. PLoS One 6:e18500. CrossRef Medline

Mackey E, Ayyadurai S, Pohl CS, D’ Costa S, Li Y, Moeser AJ (2016) Sexual dimorphism in the mast cell transcriptome and the pathophysiological responses to immunological and psychological stress. Biol Sex Differ 7:60. CrossRef Medline

Mandy W, Chilvers R, Chowdhury U, Salter G, Seigal A, Skuse D (2012) Sex differences in autism spectrum disorder: evidence from a large sample of children and adolescents. J Autism Dev Disord 42:1304-1313. CrossRef Medline

McCarthy MM (2008) Estradiol and the developing brain. Physiol Rev 88: 91-124. CrossRef Medline

McCarthy MM, Nugent BM, Lenz KM (2017) Neuroimmunology and neuroepigenetics in the establishment of sex differences in the brain. Nat Rev Neurosci 18:471-484. CrossRef Medline

Nautiyal KM, Dailey CA, Jahn JL, Rodriquez E, Son NH, Sweedler JV, Silver R (2012) Serotonin of mast cell origin contributes to hippocampal function. Eur J Neurosci 36:2347-2359. CrossRef Medline

Nopoulos P, Flaum M, Andreasen NC (1997) Sex differences in brain mor- 
phology in schizophrenia. Am J Psychiatry 154:1648-1654. CrossRef Medline

Patel SD, Brennan G, Brazin J, Ciardiello AJ, Silver RB, Vannucci SJ (2013) Mast cell isolation from the immature rat brain. Dev Neurosci 35:265271. CrossRef Medline

Schaafsma SM, Pfaff DW (2014) Etiologies underlying sex differences in autism spectrum disorders. Front Neuroendocrinol 35:255-271. CrossRef Medline

Schwarz JM, Bilbo SD (2012) Sex, glia, and development: interactions in health and disease. Horm Behav 62:243-253. CrossRef Medline

Silver R, Curley JP (2013) Mast cells on the mind: new insights and opportunities. Trends Neurosci 36:513-521. CrossRef Medline

Suzuki K, Sugihara G, Ouchi Y, Nakamura K, Futatsubashi M, Takebayashi K, Yoshihara Y, Omata K, Matsumoto K, Tsuchiya KJ, Iwata Y, Tsujii M, Sugiyama T, Mori N (2013) Microglial activation in young adults with autism spectrum disorder. JAMA Psychiatry 70:49-58. CrossRef Medline

Theoharides TC, Angelidou A, Alysandratos KD, Zhang B, Asadi S, Francis K, Toniato E, Kalogeromitros D (2012) Mast cell activation and autism. Biochim Biophys Acta 1822:34-41. CrossRef Medline
VanRyzin JW, Yu SJ, Perez-Pouchoulen M, McCarthy MM (2016) Temporary depletion of microglia during the early postnatal period induces lasting sex-dependent and sex-independent effects on behavior in rats. eNeuro 3: ENEURO.0297-16.2016. CrossRef Medline

Werling DM, Parikshak NN, Geschwind DH (2016) Gene expression in human brain implicates sexually dimorphic pathways in autism spectrum disorders. Nat Commun 7:10717. CrossRef Medline

Wright CL, McCarthy MM (2009) Prostaglandin E2-induced masculinization of brain and behavior requires protein kinase A, AMPA/kainate, and metabotropic glutamate receptor signaling. J Neurosci 29:13274-13282. CrossRef Medline

Wu MV, Manoli DS, Fraser EJ, Coats JK, Tollkuhn J, Honda S, Harada N, Shah NM (2009) Estrogen masculinizes neural pathways and sexspecific behaviors. Cell 139:61-72. CrossRef Medline

Wu Y, Dissing-Olesen L, MacVicar BA, Stevens B (2015) Microglia: dynamic mediators of synapse development and plasticity. Trends Immunol 36:605-613. CrossRef Medline

Zucker KJ, Bradley SJ (1995) Gender identity disorder and psychosexual problems in children and adolescents. New York, NY: Guilford. 